This is the final peer-reviewed pre-publication version of:

Belletti, B., Rinaldi, M., Buijse, A.D., Gurnell, A.M., Mosselman, E (2015) A review of assessment methods for river hydromorphology. Environmental Earth Sciences 73: 2079-2100

which can be accessed at http://dx.doi.org/10.1007/s12665-014-3558-1

\title{
A review of assessment methods for river hydromorphology
}

B. Belletti ${ }^{\mathrm{a}, *}$, M. Rinaldi ${ }^{\text {a }}$, A.D. Buijse ${ }^{\mathrm{b}}$, A.M. Gurnell ${ }^{\mathrm{c}}$, E. Mosselman ${ }^{\mathrm{b}, \mathrm{d}}$

${ }^{a}$ Department of Earth Sciences, University of Florence, Italy

${ }^{b}$ Deltares, the Netherlands

${ }^{c}$ Queen Mary University of London, UK

${ }^{d}$ Delft University of Technology, the Netherlands

* Corresponding author: Via S.Marta 3, 50139, Firenze, Italy, Tel: ++390554796225; Fax:++39055495333; E-mail: barbara.belletti@unifi.it

\begin{abstract}
Numerous hydromorphological assessment methods have been developed in different countries during recent decades, with notable differences in their aims, scales, and approaches. Although these methods are increasingly applied to support river management, the strengths and limitations have been insufficiently investigated. This review of 121 methods analyses hydromorphological assessment methods dating from 1983 to 2013, identifying their main strengths, limitations, gaps, the potential to integrate different approaches, and the needs for further improvements.

For this purpose methods have been grouped into four categories: (1) physical habitat assessment; (2) riparian habitat assessment; (3) morphological assessment; (4) assessment of hydrological regime alteration.

17 categories of information covering general characteristics, recorded features and river processes encompassing over 90 features were recorded for each method reviewed, allowing a comparative analysis of the four assessment categories. The main gap in most methods is insufficient consideration of physical processes. Thus, an integrated hydromorphological analysis is recommended, where the morphological and hydrological components are the key parts to classify hydromorphological conditions. Additional physical and riparian habitat methods strengthen the link with ecological conditions.
\end{abstract}

\section{Keywords}

Hydromorphology, Physical habitats, Riparian habitats, Hydrological regime, Morphological alteration 


\section{Introduction}

In recent decades, hydromorphology has been developed as an umbrella discipline that links hydrology and geomorphology. It places the consideration of physical stream characteristics and processes at the centre of river management and restoration (Newson and Large 2006; Vaughan et al. 2009). Within Europe, its has developed rapidly and numerous methodologies have been proposed following the introduction of the EU Water Framework Directive (WFD; European Commission 2000). To assess and monitor all European water bodies the WFD requires incorporating hydromorphology, in particular the hydrological regime (i.e. quantity and dynamics of water flow and connection to groundwater bodies), river morphology (i.e. channel dimensions and mobility, river bed structure and substrate calibre, and the structure of the riparian zone), and river continuity. Hydromorphological assessment can be defined to evaluate and classify both hydrological and geomorphological stream conditions. It includes those methods and procedures that identify and characterize hydromorphological features to assess river conditions. The many existing methods vary widely in terms of their concepts, aims, spatial scales, collected data and therefore their applicability.

Towards the end of the $20^{\text {th }}$ century, hydromorphological assessment mainly focussed upon occurrence and spatial configuration of physical habitats (e.g., Platts et al. 1983; Plafkin et al. 1989; Raven et al. 1997, 2002). This because physical habitats were recognized as an important component in ecological studies aimed at explaining distributional patterns of organisms, and the composition and structure of biological communities (Fernández et al. 2011). During the last decade, it has been recognised that broader river condition assessments are needed that go beyond an inventory of physical habitats by including "pressure" or "response" variables with a stronger emphasis on river dynamics and processes (Fryirs et al. 2008). However, merging the full range of disciplinary approaches necessary to assess river conditions (hydrology, geomorphology, water quality, biology, ecology) in a cost-effective and integrated way remains a challenge.

There have been a number of recent reviews of hydromorphological assessment methods that emphasise river habitat characterization (e.g., Weiss et al. 2008; Fernández et al. 2011), and there have also been attempts to standardise these habitatbased methods (CEN 2002; Parsons et al. 2004). However, many new promising methods- employing a wider range of geomorphological concepts and approaches; have been proposed in the last decade. Moreover the need and wish to apply assessment methods of hydromorphology has expanded rapidly following the adoption of the WFD. Indeed hydromorphological assessment is now carried out by many public agencies or subcontracted to consultancies, particularly within the European Union as a part of WFD implementation. Nevertheless often there is still insufficient awareness of the limitations and strengths of different methods, and how they should be integrated to ensure a comprehensive assessment.

In response to these needs, an extensive review analysis of existing hydromorphological methods (Rinaldi et al. 2013b) has been carried out in the context of REFORM (REstoring rivers FOR effective catchment Management; http://www.reformrivers.eu/), a collaborative EU project targeted to develop guidance and tools to make river restoration and mitigation measures more cost-effective. The review widened the scope compared to recent published reviews that mainly focussed 
on river habitat characterization (Raven et al. 2002; McGinnity et al. 2005; Weiss et al. 2008; Fernández et al. 2011). It extended Fernández et al. (2011), who reviewed 55 mainly habitat-based assessment methods that have been developed worldwide, by incorporating a total of 121 methods. It identified the main strengths, limitations and gaps in existing methods, and proposed future directions for hydromorphological assessment. It also touched on methods specifically developed and applied in Europe, in relation to the implementation of the WFD. The review did not aim to discuss the scientific principles nor the concepts that underlie hydromorphological and river condition assessments, since these have already been are-reviewed recently (e.g. Fryirs et al. 2008), but it aimed to compare and discuss methods in a critic way, starting from the knowledge and expertise of the authors. The paper summarises the main outcomes of Rinaldi et al. (2013b).

\section{Scope of the review}

The range of application of the methods considered in this review varies from those applicable to small, wadeable streams to those suited to relatively large, non-wadeable rivers. It is restricted to physics-based assessments, i.e. methods that address all or some of the physical elements required for a hydromorphological evaluation. Therefore, methods for the assessment of longitudinal fish continuity are not included, as they have a biological focus, although they were included in the broader review of Rinaldi et al. (2013b). It also excludes physical habitat simulation models and environmental flows methods, as they differ in structure and approach from the truly hydromorphological (i.e. hydrological and geomorphological) assessments considered here. Indeed, habitat simulation and environmental flow methods aim to identify habitats and flow requirements, respectively, needed to achieve or maintain a specified river condition (Arthington 1998; King et al. 2008), rather than to directly assess hydromorphological condition, alteration and pressures. For some examples of habitat modelling approaches see Rinaldi et al. (2013b), and for environmental flows; refer to Arthington (1998), King et al. (2008) and to the recent review of Poff and Zimmerman (2010).

The 121 methods reviewed are listed in Table 1.

\section{Categories of Methods}

An initial inspection of these hydromorphological methods revealed four broad categories of assessment, although a sharp delineation is difficult and some overlap between types inevitably exists. These were identified based on their main focus and objectives of each method, which were reflected in the spatial scales of application (Fig. 1): physical habitat assessment ( $\mathrm{PH})$, riparian habitat assessment $(\mathrm{RH})$, morphological assessment (M) and assessment of hydrological regime alteration (HRA).

A temporal trend is apparent in the development and application of different approaches (Fig. 2). The earliest assessment methods started to appear at the beginning of the 1980s. Until the end of the 1990s, proposed methods can mainly be described as physical habitat survey procedures. This first phase reflects the progressive development of river restoration techniques, which initially consisted of rather small-scale, localized interventions for habitat improvement. The introduction 
of the WFD marked a notable increase in the number of new methods developed in Europe, but most of these continued to be physical habitat surveys. Only in recent years, has a significant increase in morphological and hydrological methods occurred, as a consequence of the increasing need to use catchment-wide and process-oriented approaches for implementing river restoration projects.

Methods for physical habitat assessment

This category includes methods and protocols for the survey, characterization, and classification of physical habitat elements which can be described as river habitat surveys or physical habitat assessments (e.g., Platts et al. 1983; Plafkin et al. 1989; Raven et al. 1997; Ladson et al. 1999; National Environmental Research Institute 1999; LAWA 2000, 2002a, b). These focus mainly on instream habitats or microhabitats, but generally they also include some consideration of riparian habitats. Methods that aim to evaluate the overall functioning of the stream (e.g., method 39; Table 1) by including information on ecology-related features, are also included in this category, although they are not strictly habitat survey methods. Seventy-three physical habitat assessment methods were identified, illustrating that this type of assessment remains the most common approach for assessing the hydromorphological state of a river (Table 1, Fig. 2).

\section{Methods for riparian habitat assessment}

Riparian zones are an integral component of riverine systems, since their lateral and vertical structures depend upon hydromorphological processes. However, the development of specific methods for assessing riparian conditions is relatively recent (Fig. 2). Some indicators of riparian conditions are often included in one of the other types of assessment methods, but this particular category consists of methods that are specifically designed for the characterization of habitats in the riparian zone (e.g., Munné and Prat 1998), including some assessments of wetland ecosystem functioning (methods 74, 78; Table 1). Fifteen riparian habitat methods were identified (Table 1).

\section{Methods for morphological assessment}

This category includes methods with the following distinctive characteristics differing from the category of physical habitat assessment: (1) they make a broader evaluation of river conditions including assessing channel forms, geomorphic adjustments, and human alterations; (2) the spatial scale is typically the 'reach' scale, i.e. a variable length with sufficiently homogeneous morphological characteristics and boundary conditions.

Following the development of physical habitat assessment methods, this type of broader assessment of river conditions has emerged, particularly during the last decade (Fig. 2). In this regard, Fryirs et al. (2008) suggest that a clear distinction should be made between a river audit and a river condition assessment. A river audit permits assessment of river status by generating information on the presence and frequency of physical habitats and their characteristics. A river condition assessment is a broader evaluation which places greater emphasis on physical processes, and aims to measure both pressure and response variables (i.e. hydromorphological and 
biological indicators) as a basis for developing a clearer understanding of the causeeffect relationships that regulate observed changes in system conditions. The 'morphological assessment' category contains methods that can be described as river condition assessments. A total of 22 methods were identified (Table 1).

Methods for the assessment of hydrological regime alteration

This category encompasses a further, independent, group of methods that produce hydrological assessments, particularly the development of specific indicators of hydrologic alteration (method 118; Table 1; Richter et al. 1996; Poff et al. 2003), which can support assessments of the alteration of the natural hydrological regime. The output of these assessments is usually an index of the degree of deviation from unaltered conditions. As previously noted, the related environmental flows methods are not included in this review because their specific aim is an evaluation of flow requirements for aquatic ecosystems and species, rather than a direct assessment of the flow regime and its alterations (Arthington 1998; King et al. 2008; Poff and Zimmerman 2010). A total of 11 hydrological methods were identified (Table 1).

\section{Methodology}

Each method was analyzed, drawing mainly on information found in scientific papers and, where available, technical reports. In some cases, additional information was requested from authors or practitioners who were directly involved in the development or use of specific methods.

The type (category) of each assessment method was identified, and then (a) the characteristics of the method, (b) the features that were recorded, and, when appropriate, (c) the river processes that were assessed, were extracted. The types of extracted information are summarised in Table 2 (a more detailed description is reported in Rinaldi et al. 2013b). The way in which these three main types ((a) to (c)) of information were collected, differed slightly across the different assessment categories. In particular, information regarding the hydrological regime assessment methods (HRA) differed from the first three categories (i.e., $\mathrm{PH}, \mathrm{RH}, \mathrm{M}$ ):

(a) Method characteristics. These concerned data collection methods or sources (e.g., field survey, remote sensing, etc.); the type of method (e.g., qualitative characterization, assessment by a quantitative index); whether the method makes use of some type of reference conditions; the spatial scale of the assessment, including the zones of the river corridor that were surveyed; and the temporal scales of investigation. There are several approaches used to define reference conditions, including: (i) empirical data from reference sites; (ii) historical information (i.e. some historical state is assumed as a reference condition); (iii) modelled reference; (iv) theoretical reference; (v) based on expert judgement; (vi) based on the historic range of variability or evolutionary sequence and ergodic reasoning (Brierley and Fryirs 2005). For hydrological assessment methods, additional information was collected concerning the predictive ability of the assessment, whether methods make a direct link to ecology, and the particular strengths of a method (i.e., ease of application, ability to use variable data series lengths, ability to be applied both to gauged and ungauged catchments, inclusion of an assessment of pressures a priori). 
(b) Recorded features. These represent the core of the review, since they highlight differences between the categories of assessment. In the case of physical habitat, riparian habitat, and morphological assessment, they comprise lists of hydromorphological features recorded in various portions of the river corridor (instream, banks, riparian areas, floodplain). For the hydrological assessment methods, these include metrics of hydrological characterization, alteration and pressures.

(c) River processes. These are only relevant to the first three categories of assessment, and provide information on whether any specific physical river process is included in the evaluation (e.g., longitudinal, lateral and vertical continuity, bank processes, channel adjustments).

\section{A comparative analysis of hydromorphological assessment methods}

Based upon the characteristics, information, and, where relevant, river processes incorporated within each assessment, the following sections provide a summary of the properties of the assessment methods within each of the four categories (physical habitat, riparian habitat, morphological, hydrological regime alteration).

The percentage of methods within each category covering the different characteristics, recorded features and river processes is summarized in Table 2, Fig. 3 and Fig.4.

Methods for physical habitat assessment

Most physical habitat assessments are based on extensive field surveys. Maps and remote sensing techniques are also frequently used for preliminary reconnaissance of the river and to allow for reach delineation.

$78 \%$ of physical habitat assessment methods generate one or more indices that evaluate hydromorphological condition. These indices are usually derived from the inventory of recorded features (e.g., 12, 31; note numbers refer to methods listed in Table 1), although some methods also aim at evaluating the overall functioning of the stream ( $6 \%$ of methods), by including information on ecology-related features (e.g., method 39; Table 1). Some form of reference conditions are also explicitly incorporated in $58 \%$ of the reviewed methods.

The spatial scale of most physical habitat assessments is rather small, coinciding with what might be described as a site scale, i.e. a river length in the order of a few hundred meters. The longitudinal length of each site or reach may be either fixed (e.g., $500 \mathrm{~m}$ ) or variable, in the latter case the length reflects larger--scale characteristics (e.g., geology and climate, presence of longitudinal discontinuities, etc.). All reviewed methods focus on the channel; most include the river banks and riparian areas; but less than $75 \%$ extend to the surrounding floodplain. Concerning their temporal scale, all reviewed methods assess the present state of the river at the time of survey, while very few include information on recent or historical river conditions (45; Table 1).

Channel features usually include channel dimensions, dominant bed sediment size and composition, channel forms and geomorphic units (e.g., number of riffles and pools), and artificial features (e.g., dams, weirs, culverts, deflectors, etc.). The physical 
structure of the banks and the presence of artificial elements are the most commonly recorded features of riverbanks and riparian zones. Land use and the presence of fluvial forms (e.g., oxbow lakes, wetlands) are the most commonly-recorded floodplain features. Information on large--scale catchment and valley characteristics is rarely included, and hydrological information is only provided to characterize the condition at the time of the survey (e.g., estimation of discharge). However, in some countries (e.g., Australia), the hydrological assessment is more detailed and considers several properties of the river regime (e.g., Ladson et al. 1999; Parsons et al. 2004).

In relation to river processes, longitudinal and lateral continuity are often assessed based on the presence of artificial features, while only $12 \%$ of methods include some consideration of channel adjustments (i.e. widening/narrowing, aggradation/degradation).

\section{Methods for riparian habitat assessment}

As for physical habitats, the assessment of riparian habitats is mainly undertaken using extensive field assessment protocols, while the use of maps and remote sensing is rare (Fig. 3; Table 2; but see method 87, Table 1).

The assessment approach varies, ranging from the use of indices or quality classes, to the application of inventory protocols often including sampling of vegetation community composition (e.g., 75, 84; Table 1). A relatively low proportion (40\%) of the methods makes explicit use of reference conditions (e.g., 87; Table 1).

Riparian habitat assessment is usually undertaken at the reach scale, which is larger than the site scale that is generally employed in river habitat assessments. The area or length that is surveyed is variable and has relatively homogenous vegetation characteristics. Similar to physical habitat assessment, the temporal scale of investigation is restricted to the time of the survey.

In terms of the recorded features, these methods focus on banks and riparian zones. About $50 \%$ of the investigated methods record channel features, and mainly focus on the width of the channel in relation to vegetated areas such as islands and vegetated bars, and artificial features. The vegetation features most commonly assessed include vegetation structure, species coverage, and species composition, with a special emphasis on the presence and abundance of non-native species (particularly in European methods). Some methods place emphasis on the temporal dynamics of vegetation pattern (i.e. evidence of vegetation regeneration, for example, in terms of the presence of seedlings).

Most of the methods evaluate longitudinal and lateral vegetation continuity which provides insights into the lateral connectivity between the riparian area and its river and floodplain. Only a small proportion attempts to relate the riparian habitat to physical processes.

\section{Methods for morphological assessment}

As for the previous categories, field survey is the predominant method of datagathering, but morphological assessments make more extensive use of remote sensing data and maps (73\%; Fig. 3, Table 2). 
Morphological methods are mainly used for: (i) an evaluation framework of river conditions (e.g., 97, 103; Table 1); (ii) an assessment supported by one or more indices (e.g., 102, 110; Table 1); or (iii) an assessment directed towards restoration design (e.g., 92; Table 1). Some methods provide a risk assessment of existing pressures rather than an analysis of morphological conditions (e.g., 104; Table 1). In some cases the assessment provides a morphological characterization that is included in broader protocols for evaluating the river or watershed conditions (e.g., 96, 99; Table 1). Lastly, some morphological methods are used in combination with the assessment of other ecosystem components to provide an evaluation of the overall river conditions (Healey et al. 2012). $64 \%$ of methods include the use of reference conditions.

Compared to the previous categories, morphological assessment is generally carried out at a larger spatial scale, which could still be termed the reach scale, i.e. a length in the order of a few kilometres with sufficiently homogeneous morphological characteristics and boundary conditions. In most cases $(>80 \%)$, the assessment concerns the entire river corridor (i.e. channel, banks, riparian zones, and floodplain). In a temporal context, a larger proportion of these methods take account of recent and historical channel adjustments through the use of maps and remote sensing.

Compared to physical habitat methods, the assessment of channel features is more focussed on channel pattern and physical variables, but less on the survey of instream habitats (e.g. instream vegetation, large wood accumulations, flow types). Although some characterization of bed sediment is incorporated within most methods, relatively few methods attempt to evaluate substrate structure alterations such as armouring and clogging (or embeddedness) (see methods 105, 109, 110; Table 1). Bank morphology, artificial features in the riparian zone, and floodplain forms and features are considered to some extent by most of the morphological methods. More than $80 \%$ evaluate hydrological alterations, although usually only in qualitative terms.

Many also include some consideration of river processes, including sediment transport (for continuity), bank erosion, and channel adjustments.

Methods to assess hydrological regime alteration

The main characteristics of this category of assessment are summarised in Figure 43 and Table 2.

This type of assessment mainly involves the processing of existing hydrological data series or the use of modelled data. Numerical models are required when data are not available or to fill gaps in incomplete data series (e.g., 120; Table 1). Maps and remote sensing can be used to support the evaluation of human pressures at the catchment scale or for characterizing the river or catchment (50\% of methods). Field measurements of river discharge may be included in the assessment (e.g., 115; Table 1), particularly for ungauged reaches (e.g., 120; Table 1).

Most of the methods produce a final single index or multiple indices. Given their predictive ability, some are used to build scenarios for evaluating the success of restoration or the impact of specific river changes (e.g., 117; Table 1). Reference conditions are often used, and consist of undisturbed or pre-impact conditions based on existing data or on modelling results (64\% and $27 \%$ respectively). 
The spatial scale of application varies widely from the reach (the most common scale) to the segment (i.e. a macro-reach of tens of kilometres) or to the entire catchment.

$46 \%$ of methods link explicitly with ecological components. For example they may assess the ecological response to changes in the hydrological regime in order to evaluate the present ecological status (114; Table 1).

Concerning the recorded features, almost all make use of river discharge data. In the cases where field data are required, cross-sections, flow velocity and depth are generally measured (e.g., 115; Table 1). Some methods (e.g., 112; Table 1) also combine watershed land use characteristics (e.g., coverage, density) with hydrological data. Almost all are based on the five main components of the flow regime: discharge magnitude, frequency, duration, timing, rate of change (Richter et al., 1996, Poff et al., 2003). Some also evaluate temporal variability (i.e., annual/seasonal, interannual/climatic changes) (e.g., 116; Table 1).

In terms of assessed pressures, the effects of impoundments, water abstractions and diversions are commonly evaluated, while none of the reviewed methods assess the effects of hydro-peaking from power generation plants.

\section{Strengths, limitations and gaps in assessments}

Based on the above review of existing assessment techniques, this section identifies strengths and limitations within each of the four categories (Table 3). This is supplemented by the authors' expert opinion on the pros and cons of the methods implemented and applied by EU countries within the context of the WFD.

\section{Methods for physical habitat assessment}

These methods have a number of strengths. They provide a framework within which habitat units can be efficiently inventoried and sampled, and so they are useful for characterizing the range of physical habitats that are present, their heterogeneity and the contemporary physical structure of ecosystems. Additionally, these methods often inventory some features of ecological relevance, which are not addressed within the other categories, such as the presence of refuge areas, organic matter, shading, etc. (e.g., 12, 40; Table 1). Therefore, they are potentially helpful in establishing links between morphology and ecological conditions and communities (e.g., supporting explanation of the distribution patterns of organisms, the composition and structure of biological communities or aspects of ecosystem functioning). Finally, some of these methods have been used quite widely across Europe (e.g., method 12, Table 1, and similar procedures developed in other countries), allowing comparison of data and results from different regions.

Nevertheless, physical habitat assessments have several shortcomings. First, these methods have long been considered to be equivalent to hydromorphological assessment, but they are now recognised to represent only one component of a hydromorphological evaluation, which is mainly the occurrence of habitats. Indeed, when physical habitat methods are used with the aim of understanding physical processes and causes of river alterations, they generally fail (e.g. Fryirs et al. 2008, Entwistle et al. 2011). 
More specifically, the spatial scale of investigation (i.e., the site scale of a few hundred meters) is usually inadequate for the accurate diagnosis and interpretation of the causes of any morphological alteration. This is because physical site conditions commonly originate from processes and causes that operate at larger spatial scales (e.g., Frissel et al. 1986; Brierley and Fryirs, 2005).

Additionally, physical habitat assessment methods require very detailed site-specific data collection, such that their application to large numbers of water bodies may be impractical. These methods also make limited use of geomorphological approaches other than field surveys (Table 2; Fig. 3). The expansion of these assessments to incorporate remotely sensed data and GIS analysis-, would permit wider spatial and temporal scales of analysis, and more informative assessments. As a consequence, observations tend to be viewed in a static way, rather than placing them in the temporal context within which channel processes operate and river channels adjust. This primary limitation prevents the development of a sound understanding of hydromorphological responses to pressures (i.e. cause-effect relationships), which is essential for identifying and subsequently implementing appropriate rehabilitation actions (Kondolf et al. 2003; Fryirs et al. 2008).

The use of reference conditions based on statistical analyses of empirical data is also questionable. Selection of a sufficient and representative number of reference sites can be problematic, given that many different morphological typologies should be represented. The choice of natural sites is also prone to errors, because sites without artificial elements could still be morphologically altered by disturbances occurring in other parts of the river network (upstream or downstream) or that may have occurred in the past. Moreover, these procedures tend to identify high status conditions with maximum morphological diversity for all types of rivers, failing to recognize that in some cases the natural geomorphic structure of a particular stream type may be very simple whereas in other cases it may be more complex (Barquín et al. 2011; Fryirs 2003).

Additional limitations can be identified in the way that physical habitat methods characterize channel forms and geomorphic units. These concern a notable gap in the terminology used to describe geomorphic units in most habitat surveys when compared to the present state of the art in fluvial geomorphology. For example, most refer only to riffles and pools when describing the configuration of the river bed, probably because most habitat survey methods have been developed to address small single-thread, sand-bed or gravel-bed rivers. As a result, there is incomplete consideration, for example, of the wide variety of bed morphologies found in steep, mountain, cobble- or boulder-bed streams, where other geomorphic units may occur (cascades, rapids, glides, step-pools, etc.). Although considerable progress has been made recently in the description and terminology associated with geomorphic-units found in mountain streams (e.g., Halwas and Church 2002; Comiti and Mao 2012), this post-dates the development of most physical habitat assessment methods, and this progress has been insufficiently incorporated by updating these methods. The variety of bed morphologies found in large lowland rivers is also poorly incorporated (e.g., dune-ripple morphologies). Similarly, geomorphic units found in rivers with complex, transitional or multi-thread patterns (i.e., wandering or braided) are not adequately covered, although some effort has been made recently to represent some of these morphologies (including ephemeral or temporary streams typical of some Mediterranean regions in Southern Europe; e.g., 54, Table 1). In the case of large 
rivers with complex morphologies (e.g., many piedmont Alpine rivers), field surveys alone are inadequate to characterize channel forms and geomorphic units, and so the incorporation of remote sensing techniques is essential. Furthermore, considerable progress has been achieved recently in developing new procedures whereby the identification and analysis of individual landforms (geomorphic units) is set in a more appropriate spatio-temporal framework (e.g., Fryirs and Brierley 2013; Brierley et al. 2013), but this type of approach has not been incorporated into any of the analysed methods.

Methods for riparian habitat assessment

Many of the strengths and shortcomings of physical habitat assessments also apply to riparian habitat assessments since they usually adopt a similar approach. However, riparian habitat assessments also have some specific strengths, since they integrate well with physical habitat assessments by extending their coverage from the river channel into the riparian zone, and also giving more emphasis to vegetation, particularly riparian vegetation. Therefore, they are extremely important in accomplishing a requirement of the WFD, which is to give consideration to vegetation as a key biological as well as hydromorphological element.

While most of these methods are based on field survey and some are still focussed on the site scale, others methods make use of other information sources and approaches (e.g., integrated use of remote sensing and field survey) and a larger spatial scale (reach) that can be integrated with other hydromorphological methods allowing an overall river condition assessment (e.g., 87; Table 1).

Despite these specific strengths, many riparian habitat assessments are essentially an inventory of habitats and vegetation conditions observed along a portion of river. As a result, there is limited consideration of the processes generating riparian conditions and the causes of alteration at larger spatial and temporal scales.

This type of assessment is not widely used yet. In the U.S., riparian assessment is often coupled with the assessment of wetland ecosystem functioning (e.g., 78; Table 1). In Europe, most methods have been developed in Mediterranean countries (e.g., Spain, Italy), where flashy flow regimes and ephemeral, multi-channel patterns (incorporating vegetated islands) are more frequent, determining a more complex riparian forest structure. This regional bias means that the validity of many of the techniques is uncertain if they were to be applied to other climatic, hydrological and morphological conditions. Additionally a regional bias could also exist in terms of human impacts (e.g., the predominance of water abstraction and sediment input budget changes in southern European countries in comparison with the predominance of vegetation management / removal and pollution in northern ones).

\section{Methods for morphological assessment}

Compared to the previous two categories, these methods make use of a more robust geomorphologically-based approach by integrating information drawn from remote sensing and field survey, with a stronger consideration of physical processes at appropriate spatial and temporal scales. Such an approach goes beyond an inventory 
of forms to support the development of a better understanding of cause-effect relationships.

In most cases the basic spatial unit for the application is the reach scale, commonly a few kilometres in length, where reaches are identified in a geomorphologicallymeaningful way, as sections of river along which present boundary conditions are relatively uniform.

Additionally, some methods account explicitly for the temporal component by incorporating a historical analysis of channel adjustments to provide insights into the timing and causes of alterations and into potential future geomorphic changes (e.g., 110; Table 1). Understanding evolutionary trajectories and past changes is an important component when assessing contemporary river conditions. Morphological indicators should take account of how rivers have changed through time (Brierley and Fryirs 2005; Fryirs et al. 2008).

Some of these strengths could also be interpreted to some degree as limitations. Physical processes are generally more difficult to assess than a simple inventory of existing forms. A rigorous evaluation of processes requires the collection of measurements at different times and process rates (e.g., bank erosion or deposition), quantitative modelling or analyses of changes in the process regime (e.g., alterations in sediment transport or water discharge regime), all of which are unlikely to be feasible within the context of a relatively rapid hydromorphological assessment. For practical reasons, recorded indicators of processes are thus often generated from a static visual assessment of the occurrence or not of active processes (observed in the field or based on remotely-sensed information). In other cases, the evaluation is indirectly based on the presence of artificial elements, which are inferred to have significant impacts on some processes. For example, the simple presence of transverse structures is often assumed to alter sediment fluxes and continuity, without any quantitative evaluation of the magnitude of their effects. Even though some morphological assessment methods explicitly account for the temporal component by considering channel adjustments (i.e. changes of channel form through time), this analysis is often prone to errors because it is difficult and requires specialist expertise, specific analyses (e.g., GIS analysis of channel planimetric changes), as well as high spatial and temporal resolution data. The definition of a reference state for morphological conditions is even more problematic than for the other categories. Some morphological assessments implicitly incorporate the assumption that the past state is a reference condition. However, where a more rigorous approach is attempted, a common vision of reference conditions is lacking (Bertoldi et al. 2009; Dufour and Piégay 2009; Rinaldi et al. 2013a), leading to the application of non-harmonized definitions of reference conditions.

The focus of morphological assessments is generally on fluvial forms and processes at wider spatial and temporal scales than physical habitat assessment, but the vertical component of river continuity (i.e., the connection to groundwater) is still poorly considered (Table 2; Fig. 3). Limited attention is also given to a systematic inventory of the geomorphic units and assemblages that characterize a given morphology and are useful for ecosystem characterization. The latter can be a severe limitation when morphological assessment is used alone.

Lastly, these methods evaluate morphological conditions exclusively in terms of physical forms or processes, without any inferences concerning their consequences or 
implications in terms of ecological state. This means that a high morphological quality is not necessarily related to a good ecological state, although this is most likely the case, since many authors suggest that functioning of physical processes and dynamic equilibrium promote ecosystem diversity and functioning (e.g., habitat heterogeneity; Tockner and Ward 1999; Rinaldi et al. 2013a). However a clear relation between some of the morphological indicators used in these methods and biological responses is currently lacking.

Methods for the assessment of hydrological regime alteration

The main strength of this category of assessment is that it makes use of well-defined indicators based on quantitative assessments, statistical analyses or physics-based models. For example, most methods employed within Europe are based on some or all of the Indicators of Hydrologic Alteration (IHA) proposed by Richter et al. (1996) and Poff et al. (2003).

The drawback is that such indicators and models generally require large data sets and long-time series, which are often not available. In particular, applying these methods to ungauged streams is problematic. If models are applied when data are not available or incomplete, the uncertainties that can affect the estimation should be carefully considered.

A further critical issue is defining the unaltered (natural) reference hydrological regime. This requires a sufficiently long, mostly non-existing data series from preimpact conditions. Assuming that 'pre-impact' data series related to a particular intervention (e.g., dam construction) to represent natural conditions is rarely appropriate, particularly in Europe where river systems and their hydrological regime have been affected over many centuries by numerous and continuing alterations at a catchment scale (Rinaldi et al. 2013c).

Indicators of hydrological alteration are usually based, at best, on daily discharges. This prevents the analysis of hydrological alterations that occur at shorter time scales, such as hydropeaking (as well as thermopeaking), that have very important effects on ecological communities (e.g., Paetzold et al. 2008; Person and Peter 2012). Specific indicators or models for analyzing hydropeaking are needed. Recent progress has been made to develop integrating approaches and key indicators to assess hydrological alterations due to hydropower impacts (e.g., Zolezzi et al. 2009; Meile et al. 2011). These should be incorporated to further improve hydrological assessment methods.

Like other categories, the effects of groundwater alterations are generally not included apart from an indirect assessment through low-flow analyses. Groundwater systems are an important component of riverine ecosystems and methods are needed to incorporate them into assessments in a more detailed way.

Because of the above limitations, the practical use of these methods for supporting hydromorphological assessment is still modest. An alternative and more feasible approach might be an analysis of existing hydrological pressures, based on the presence and type of impacts and causes of alteration (e.g., 112, 121; Table 1). However, it can be extremely difficult to correctly evaluate the effects of a given pressure in the absence of a quantitative analysis of hydrological data. Merging of these two types of approach has been achieved in relation to developing 
environmental flow methods, but with the aim of defining flow requirements for the proper biological functioning together with the human needs (e.g., Arthington 1998; King et al. 2008), rather than to assess regime alteration alone.

Methods implemented by EU countries in the context of the WFD

Finally, specific focus has been put on the methods which have been formally approved or are commonly used (but without formal approval) by European countries to implement the WFD, because the choice of the methods and the outcome of the assessments strongly influences decision-making on ecological status and the need for rehabilitation programmes. A more detailed analysis of these methods is provided by Rinaldi et al. (2013b). Each method is included in one of the previously defined categories (Fig. 5a), revealing that physical habitat assessment methods prevail (31, $37,38,40,44,54,60,61,64,65,68,70,73,77$; Table 1), followed by morphological methods $(101,104,105,109,110$; Table 1), while the use of riparian habitat and hydrological alteration methods is very limited ( 77 and 120, respectively; Table 1). For this analysis, an adaptation of RHS to Portugal (Raven et al. 2009; Ferreira et al. 2011) has also been included within the physical habitat assessment methods, while the three different versions of the German method have been counted only once (the overall LAWA, corresponding to methods 31,37 , and 38 in Table 1).

In most EU countries (with the exception of France and Italy) physical habitat assessments are the only methods used for the hydromorphological assessment in the context of the WFD. The limitations of each category of methods have been previously discussed, but the following points summarise current general limitations in the application of hydromorphological assessment methods within the EU:

1) A lack of consideration of physical processes is the most important omission in currently-used hydromorphological assessment methods. This omission limits development of a proper understanding of the causes of alterations and responses to them (i.e. cause-effect). Such an understanding is essential if appropriate rehabilitation actions are to be implemented (Kondolf et al. 2003; Fryirs et al. 2008).

2) Although informative, physical habitat assessment is only one component of an overall hydromorphological assessment. At present, few EU countries attempt to incorporate other components into a fully integrated hydromorphological assessment.

3) There is also currently no integration of the physical (hydromorphological) aspects with other components (i.e. water quality, biology, ecology) to give a genuinely interdisciplinary approach to overall river condition assessment (Fryirs et al. 2008).

4) For future hydromorphological assessment and monitoring, a more integrated use of more components is required to achieve an overall assessment, and a stronger emphasis within hydromorphology on morphological and hydrological methods would be beneficial.

To place these EU WFD-related assessments into a broader context and allow a more general comparison of the use of the four categories of methods worldwide, the distribution of method categories including all European methods (i.e. not only those implemented for the WFD) as well as other non-European methods is plotted in Figure $5 \mathrm{~b}$. It confirms that the most widely used category of methods worldwide is the physical habitat assessment, followed by a recent increase in the development and 
application of more morphological methods. Exceptions are South-Africa, where morphological assessments prevail, and Australia, where it seems that more interest is allocated to riparian habitats.

\section{Concluding remarks and recommendations for future developments}

Our analysis of hydromorphological assessment methods has built upon and builds extended existing reviews (Raven et al. 2002; Mc Ginnity et al. 2005; Weiss et al. 2008; Fernández et al. 2011) providing the following new insights.

Most previous reviews have a specific focus on European methods (e.g., Raven et al. 2002; Weiss et al. 2008), mainly aiming to support suitable method selection for WFD implementation. This paper started from a wider geographical perspective (similar to Fernández et al. 2011), and subsequently focussed briefly on European WFD-related assessments.

Earlier reviews focussed on physical habitat assessment often seen to be synonymous with hydromorphological assessment. This paper reviewed additionally three other assessment categories to identify the strengths and limitations of various approaches resulting in recommendations to further progress this area of assessment.

Acknowledging the identified limitations and gaps, future developments need to incorporate physical processes into hydromorphological assessment methods. This aspect is particular relevant for the more dynamic rivers with short- to mid-term habitat turnover. This can be achieved by a wider application of morphological methods to increase the capability to assess geomorphic processes rather than just physical habitat assessment. This asks for a spatio-temporal hierarchical framework with relevant units and scales, key factors and appropriate indicators to assess morphological processes and alterations.

Finally, we thus recommend developing a framework for integrated hydromorphological analysis, where the morphological and hydrological components (including vegetation as a morphological driver) are key parts to evaluate and classify hydromorphological state and quality. Moreover, to better diagnose the status of rivers and give guidance for improvement it is important to better tune this with assessment of other components, such as water quality and ecology.

In this respect, it is worth recalling that the various methodological categories reflect different conceptual approaches and disciplines (e.g., hydrology, geomorphology, biology), and that application of each specific approach requires training and background knowledge of the underlying principles. Application without the necessary background and skills could seriously limit adopting a truly integrated analysis of river ecosystems.

\section{Acknowledgements}

The work leading to this paper has received funding for the EU's FP7 under Grant Agreement No. 282656 (REFORM, Restoring rivers FOR effective catchment Management). W. Bertoldi and W. Van de Bund are acknowledged for their inputs and comments. The REFORM colleagues are acknowledged for providing information on the methods adopted for WFD implementation: N. Friberg, G. 
Geerling, M. Gielczewski, M. Gonzales del Tanago, A. Henshaw, J. Kail, B. Lastoria, S. Mariani, A. Marzin, S. Muhar, P. Pollard (REFORM Advisory Board), M.C. Perez,

P. Reichert, L. Sandin, J. Segersten, M. Staras, C. Wolter.

\section{References}

Agences de L'Eau (1998): SEQ Physique. A system for the Evaluation of the Physical Quality of watercourses. Version 0. Angers, November 1998. In: Mc Ginnity PM, Mills P, Roche W, Müller M (2005) A desk study to determine a methodology for the monitoring of the 'morphological conditions' of Irish Rivers. Final Report. Environmental RTDI Programme 2000-2006. Central Fisheries Board - Compass Informatics - EPA

Anderson JR (1993) State of the Rivers Project. Department of Primary Industries, Queensland. In: Mc Ginnity PM, Mills P, Roche W, Müller M (2005) A desk study to determine a methodology for the monitoring of the "morphological conditions' of Irish Rivers. Final Report. Environmental RTDI Programme 2000-2006. Central Fisheries Board - Compass Informatics - EPA

Arthington AH (1998) Comparative Evaluation of Environmental Flow Assessment Techniques: Review of Holistic Methodologies. LWRRDC Occasional Paper 26/98. ISBN 0642267456

Barbour MT, Gerritsen J, Snyder BD, Stribling JB (1999) Rapid Bioassessment Protocols for use in streams and wadeable rivers: periphyton, benthic macroinvertebrates, and fish. Second edition. EPA 841-B-99-002 U.S.

Barquín J, Fernández D, Álvarez M, Peñas F (2011) Riparian quality and habitat heterogeneity assessment in Cantabrian rivers. Limnetica 30(2):329-346

Bertoldi, W., Gurnell, A., Surian, N., Tockner, K., Zanoni, L., Ziliani, L., Zolezzi, G. (2009) Understanding reference processes: Linkages between river flows, sediment dynamics and vegetated landforms along the Tagliamento River, Italy. River Res Applic 25:501-516. doi: 10.1002/rra.1233

Black AR, Bragg OM, Duck RW, Rowan JS (2005) DHRAM: a method for classifying river flow regime alterations for the EC Water Framework Directive. Aquatic Conserv: Mar Freshw Ecosyst 15:427-446

Braioni MG, Penna G (1998) I nuovi Indici Ambientali sintetici di valutazione della qualità delle rive e delle aree riparie: wild State Index, Buffer Strip Index, Environmental Landscape Indices: il metodo. Biologia ambientale 6:3-38

Brierley GJ, Fryirs KA (2005) Geomorphology and river management: applications of the river style framework. Blackwell, Oxford, UK

Brierley GJ, Fryirs K, Cullum C, Tadaki M, Huang HQ, Blue B (2013) Reading the landscape: integrating the theory and practice of geomorphology to develop place-based understandings of river systems. Progress in Physical Geography 37(5):601-621

Buffagni A, Erba S, Ciampitiello M (2005) Il rilevamento idromorfologici e degli habitat fluviali nel contesto della direttiva europea sulle acque (WFD): principi e schede di applicazione del metodo Caravaggio. Istituto di Ricerca sulle Acque, CNR IRSA. Notiziario dei metodi analitici 2:32-34 
Bundesanstalt für Gewässerkunde (2001) Strukturgüte-Kartierverfahren für Wasserstraßen. In: National Environmental Research Institute and Slovak Hydrometeorological Institute (2004). Establishment of the Protocol on Monitoring and Assessment of the Hydromorphological Elements (Slovakia). Final Report

Buhmann D, Hutter G (1996) Fließgewässer in Vorarlberg. Gewässerstrukturen Erfassen - Bewerten - Darstellen. Ein Konzept. Schriftenreihe Lebensraum Vorarlberg, Band 33. In: Mc Ginnity PM, Mills P, Roche W, Müller M (2005) A desk study to determine a methodology for the monitoring of the 'morphological conditions' of Irish Rivers. Final Report. Environmental RTDI Programme 2000-2006. Central Fisheries Board - Compass Informatics - EPA

Bundesamt für Umwelt, Wald und Landwirtschaft (BUWAL) (1998) Methoden zur Untersuchung und Beurteilung der Fließgewässer. In: Mc Ginnity PM, Mills P, Roche W, Müller M (2005) A desk study to determine a methodology for the monitoring of the 'morphological conditions' of Irish Rivers. Final Report. Environmental RTDI Programme 2000-2006. Central Fisheries Board Compass Informatics - EPA

CEN (2002) A Guidance Standard for Assessing the Hydromorphological Features of Rivers. CEN TC 230/WG 2/TG 5:N32

Chandesris A, Mengin N, Malavoi JR, Souchon Y, Pella H, Wasson JG (2008) Système Relationnel d'Audit de l'Hydromorphologie des Cours d'Eau. Principes et methodes, v3.1. Cemagref, Lyon, France

Comiti F, Mao L (2012) Recent advances in the dynamics of steep channels. In: Church M, Biron PM, Roy AG (eds) Gravel-bed Rivers: Processes, Tools, Environments. John Wiley \& Sons, Ltd., pp 353-377

Crowe E, Kudray G (2003) Wetland assessment of the Whitewater watershed. Report to U.S. Bureau of Land Management, Malta Field Office. Montana Natural Heritage Program, Helena

van Dam O, Osté AJ, de Groot B, van Dorst MAM (2007) Handboek Hydromorfologie. Monitoring en afleiding hydromorfologische parameters Kaderrichtlijn Water. Directoraat-generaal Rijkswaterstaat, Waterdienst/ Dataen ICT-Dienst, Lelystad/Delft. ISBN 9789036914512

Danish Environmental Protection Agency (1998) Biological Assessment of Biological Stream Quality. Environmental Guidelines, 5. Copenhagen. In: Mc Ginnity PM, Mills P, Roche W, Müller M (2005) A desk study to determine a methodology for the monitoring of the 'morphological conditions' of Irish Rivers. Final Report. Environmental RTDI Programme 2000-2006. Central Fisheries Board Compass Informatics - EPA

Davenport AJ, Gurnell AM, Armitage PD (2004) Habitat survey and classification of urban rivers. River Res Applic 20(6):687-704

Davies NM, Norris RH, Thoms MC (2000) Prediction and assessment of local stream habitat features using large-scale catchment characteristics. Freshwater Biology 45:343-369 
Denortier G, Goetghebeur P (1996) Outil d'évaluation de la qualité du milieu physique des cours d'eau. Synthèse, Angers (Agence de l'Eau Rhin-Meuse). In: Mc Ginnity PM, Mills P, Roche W, Müller M (2005) A desk study to determine a methodology for the monitoring of the 'morphological conditions' of Irish Rivers. Final Report. Environmental RTDI Programme 2000-2006. Central Fisheries Board - Compass Informatics - EPA

Dixon I, Douglas M, Dowe J, Burrows D, Townsend S (2005) A rapid method for assessing the condition of riparian zones in the wet/dry tropics of northern Australia. 4th Australian Stream Management Conference. Department of Primary Industries, Water and Environment, pp 173-178

Dufour S, Piégay H (2009) From the myth of a lost paradise to targeted river restoration: forget natural references and focus on human benefits. River Research and Applications 25:568-581

Entwistle N, Heritage G, Milan D (2011) River Habitat Survey: A useful tool for hydromorphological assessment? Advances in River Sciences 2011, Swansea UK, Abstracts

Environment Agency (1998) River Geomorphology: a pratical guide. Environment Agency, Guidance Note 18, National Centre for Risk Analysis and Options Appraisal, London, 56 pp. In: Sear DA., Hill CT, Downes RHE (2008) Geomorphological assessment of riverine SSSIs for the strategic planning of physical restoration. Report NERR013. Natural England Research

Environment Agency (2003) A refined geomorphological and floodplain component. River Habitat Survey FD 1921, GeoRHS fieldwork survey form and guidance manual. Warrington, DEFRA/EA Joint R\&D - Project 11793, prepared by University of Newcastle

European Commission (2000) Directive 2000/60/EC of the European Parliament and of the Council of 23 October 2000 Establishing a Framework for Community Action in the Field of Water Policy. Official Journal L 327, 22/12/2000, Brussels, Belgium

Feld CK (2004) Identification and measure of hydromorphological degradation in Central European lowland streams. Hydrobiologia 516(1):69-90

Fernández D, Barquin J, Raven PJ (2011) A review of river habitat characterisation methods: indices vs. characterisation protocols. Limnetica 30(2):217-234

Ferreira J., Pádua J., Hughes S.J., Cortes R.M., Varandas S., Holmes N., Raven P. (2011). Adapting and adopting River Habitat Survey: problems and solutions for fluvial hydromorphological assessment in Portugal. Limnetica 30(2):263272

Fitzpatrick FA, Waite JR, D’Arconte PJ, Meador MR, Maupin MA, Gurtz ME (1998) Revised Methods for Characterizing Stream Habitat in the National Water Quality Assessment Program. U.S. Geological Survey Water Resources Investigations Report 98-4052. Raleigh, North Carolina. In: Mc Ginnity PM, Mills P, Roche W, Müller M (2005) A desk study to determine a methodology for the monitoring of the 'morphological conditions' of Irish Rivers. Final Report. Environmental RTDI Programme 2000-2006. Central Fisheries Board Compass Informatics - EPA 
Freiland Umweltconsulting (2001a) NÖMORPH. Strukturkartierung ausgewählter Fließgewässer in Niederösterreich. Endbericht - Teil I: Methodik. (unpublished). In: Mc Ginnity PM, Mills P, Roche W, Müller M (2005) A desk study to determine a methodology for the monitoring of the 'morphological conditions' of Irish Rivers. Final Report. Environmental RTDI Programme 2000-2006. Central Fisheries Board - Compass Informatics - EPA

Freiland Umeltconsulting (2001b) NÖMORPH. Strukturkartierung ausgewählter Fließgewässer in Niederösterreich. Endbericht - Teil II: Allgemeines und Ergebnisse. (unpublished). In: Mc Ginnity PM, Mills P, Roche W, Müller M (2005) A desk study to determine a methodology for the monitoring of the 'morphological conditions' of Irish Rivers. Final Report. Environmental RTDI Programme 2000-2006. Central Fisheries Board - Compass Informatics - EPA

Frissel CA, Liss WJ, Warren CE, Hurley MD (1986) A Hierarchical Framework for Stream Habitat Classification: Viewing Streams in a Watershed Context. Environmental Management 10(2):199-214).

Fryirs KA (2003) Guiding principles for assessing geomorphic river condition: application of a framework in the Bega catchment, South Coast, New South Wales, Australia. Catena 53:17-52

Fryirs KA, Arthington A, Grove J (2008) Principles of river condition assessment. In: Brierley G, Fryirs KA (eds) River Futures. An Integrative Scientific Approach to River Repair. Society for Ecological Restoration International, Island Press, Washington, USA, pp 100-124

Fryirs K, Brierley GJ (2013) Geomorphic Analysis of River Systems: An Approach to Reading the Landscape, Wiley, Chichester

Galli J (1996) Rapid stream assessment technique (RSAT) field methods. Metropolitan Washington Council of Governments, Washington, D.C. In: Clean Water Services, Watershed Management Division (Oregon) (2000) Tualatin River Basin Rapid Stream Assessment Technique (RSAT) - Watersheds 2000 Field Methods, Montgomery County Department of Environmental Protection; Department of Environmental Programs - Metropolitan Washington Council of Governments

González Del Tánago M, García De Jalón D (2011) Riparian Quality Index (RQI): a methodology for characterizing and assessing environmental conditions of riparian zones. Limnetica 30(2):235-254

Hallde'n A, Liliegren Y, Lagerkvist G (2002) Biotopkartering - Vattendrag. Metodik för kartering av biotoper i ochi anslutning till vattendrag. ISSN: 1101-9425. Meddelande nr 2002:55. (In Swedish). Jönköping: Länsstyrelsen i Jönköpings län. In: Molin J, Kagervall AJ et al (2010) Linking habitat characteristics with juvenile density to quantify Salmo salar and Salmo trutta smolt production in the river Savaran, Sweden. Fisheries Management and Ecology 17:446-453

Halwas KL, Church M (2002) Channel Units in Small, High Gradient Streams on Vancouver Island, British Columbia. Geomorphology 43:243-256

Harding JS, Clapcott JE, Quinn JM, Hayes JW, Joy MK, Storey RG, Greig J, Hay HS, James T, Beech MA, Ozane R, Meredith AS, Boothroyd IKG (2009) Stream 
Habitat Assessment Protocols for wadeable rivers and streams of New Zealand, University of Canterbury

Harrelson CC, Rawlins CL, Potyondy JP (1994) Stream Channel Reference Sites: An Illustrated Guide to Field Technique. General Technical Report RM-245. USDA

Healey M, Raine A, Parsons L, Cook N (2012) River Condition Index in New South Wales: Method development and application. NSW Office of Water, Sydney

Henriksen JA, Heasley J, Kennen JG, Niewsand S (2006) Users' manual for the Hydroecological Integrity Assessment Process. U.S. Geological Survey, Biological Resources Discipline, Open File Report 2006-1093

Idaho Department of Environmental Quality (2004) Beneficial use reconnaissance program field manual for streams (BURP). Beneficial Use Reconnaissance Program Technical Advisory Committee, Idaho Department of Environmental Quality, Boise

Ilnicki P, Lewandowski P (1997) Ekomorfologiczna waloryzacja dróg wodnych Wielkopolski. Bogucki Wyd. Nauk., Poznań. In: Grzybowski M, Endler Z (2012) Ecomorphological evaluation of the Łyna river along the Kotovo-Ardapy section. Quaestiones Geographicae 31(1):51-65

Ilnicki P, Gołdyn R, Soszka H, Górecki K, Grzybowski M, Krzemińska A, Lewandowski P, Skocki K, Sojka M, Marcinkiewicz M (2009) Opracowanie metodyk monitoringu i klasyfikacji hydromorfologicznych elementów jakości jednolitych części wód rzecznych i jeziornych, zgodnie z wymogami Ramowej Dyrektywy Wodnej. ETAP I - II. Zadanie 1, 2 i 3. Kod CPV: 9071 1500-9. Nomenklatura wg CPV: 90711500-9. Poznań listopad 2009 roku GEPOL sp. z o.o., Poznań. In: Ilnicki P, Górecki K, Grzybowski M, Krzemińska A, Lewandowski P, Sojka M (2010) Principles of hydromorphological surveys of Polish rivers. J Water Land Dev 14:3-13

Istituto Superiore per la Protezione e la Ricerca Ambientale (ISPRA) (2011): Implementazione della Direttiva 2000/60/CE. Analisi e valutazione degli aspetti idromorfologici. Versione 1.1. ISPRA, Roma

Jansen A, Robertson A, Thompson L, Wilson A (2005) Rapid appraisal of riparian condition. Version two. River and Riparian Land Management, Technical Guideline 4A. Canberra, Land \& Water Australia

Kaarup P (1999) Indeks for fysisk variation i vandløb. Vand og Jord nr. 6. In: Mc Ginnity PM, Mills P, Roche W, Müller M (2005) A desk study to determine a methodology for the monitoring of the 'morphological conditions' of Irish Rivers. Final Report. Environmental RTDI Programme 2000-2006. Central Fisheries Board - Compass Informatics - EPA

Kaufmann PR, Levine P, Robison EG, Seeliger C, Peck DV (1999) Quantifying Physical Habitat in Wadeable Streams. EPA/620/R-99/003. U.S. Environmental Protection Agency, Washington D.C.

Kansas Deptartment of Wildlife and Parks (2004) Subjective evaluation of aquatic habitats. Kansas Department of Wildlife and Parks, Environmental Services Section. Topeka 
King JM, Tharme RE, de Villiers MS (eds) (2008) Environmental flow assessments for rivers: manual for the Building Block Methodology. WRC Report No TT 354/08. Updated Edition. Water Research Commission, Pretoria, South Africa

Kleynhans CJ, Louw MD, Thirion C, Rossouw NJ, Rowntree KM (2005) River EcoClassification: Manual for EcoStatus determination (version 1). Joint Water Research Commission and Department of Water Affairs and Forestry, South Africa. Report No. KV 168/05

Kleynhans CJ, Mackenzie J, Louw MD (2007) Module F: Riparian Vegetation Response Assessment Index in River EcoClassification: Manual for EcoStatus Determination (version 2). Joint Water Research Commission and Department of Water Affairs and Forestry report. WRC Report No. KV 168/05

Kleynhans CJ, Louw MD, Graham M (2008) Module G: EcoClassification and EcoStatus determination. in River EcoClassification: Index of Habitat Integrity (Section 1, Technical manual) Joint Water Research Commission and Department of Water Affairs and Forestry report. WRC Report No. TT 377-08

Kondolf GM, Montgomery D, Piégay H, Schmitt L (2003) Geomorphic classifications of rivers and streams. In: Kondolf, GM, Piégay H (eds) Tools in Fluvial Geomorphology. John Wiley and Sons, Chichester, UK, Chapter 7

Ladson AR, White LJ, Doolan JA, Finlayson BL, Hart BT, Lake PS, Tilleard JW (1999) Development and testing of an Index of Stream Condition for waterway management in Australia. Freshwater Biology 41:453-468

Langhammer J (2007) HEM Hydroekologický monitoring. Metodika pro monitoring hydromorfologických ukazatelů ekologické kvality vodních toků. PřF UK, Praha, 47 pp. In: Langhammer J (2009) Applicability of hydromorphological monitoring data to locate flood risk reduction measures: Blanice River basin, Czech Republic. Environ Monit Assess 152(1):379-392

LAWA (2000) Gewässerstrukturgütebewertung in der Bundesrepublik Deutschland. Verfahren für kleine und mittelgroße Fließgewässer, Schwerin, Länderarbeitsgemeinschaft Wasser. In: Kamp U, Binder W, Holzl K (2007) River habitat monitoring and assessment in Germany. Environ Monit Assess 127(1-3):209-226

LAWA (2002a) Gewässerstrukturkartierung in der Bundesrepublik Deutschland. Verfahren für mittelgroße bis große Fließgewässer. Schwerin, Länderarbeitsgemeinschaft Wasser

LAWA (2002b) Gewässerstrukturgütekartierung in der Bundesrepublik Deutschland Übersichtsverfahren. Empfehlungen Oberirdische Gewässer. Entwurf April 2002. Länderarbeitsgemeinschaft Wasser

Lazorchak JM, Herlihy AT, Green J (1998) Rapid habitat and visual stream assessments. Section 14 In: US Environmental Protection Agency (2004): WSAss - Wadeable Streams Assessment: Field Operations Manual. Vol. EPA841-B-04-004

Lehotský M, Grešková A (2007) Fluvial geomorphological approach to river assessment - methodology and procedure. Geograficky Casopis 59(2):107-129 
Liechti P, Sieber U, Bundi U, Frutiger A, Hütte M, Peter A, von Blücher U, Willi AP, Göldi C, Kupper U, Meier W, Niederhauser P (1998) Méthodes d'analyse et d'appréciation des cours d'eau en Suisse - Système modulaire gradué, Institut fédéral pour l'aménagement, l'épuration et la protection des eaux (IFAEPE); Office fédéral de l'économie des eaux (OFEE); Amt für Abfall, Wasser, Energie und Luft (AWEL), canton de Zurich

Magdaleno F, Martínez R, Roch V (2010) Índice RFV para la valoración del estado del bosque de ribera. Ingeniería Civil 157:85-96

Martínez Santa-María C, Fernández Yuste JA (2010) IAHRIS 2.2. Indicators of Hydrologic Alteration in Rivers. User's Manual. Ministry of the Environment Polytechnic University of Madrid - CEDEX. http://www.ecogesfor.org/IAHRIS es.html

Matoušková M (2006) Dílčí zpráva z grantu GAČR 205/05/P102. Faculty of Science, Charles University in Prague. January 2006. In: Weiss A, Matouskova M, Matschullat J (2008) Hydromorphological assessment within the EU-Water Framework Directive - trans-boundary cooperation and application to different water basins. Hydrobiologia 603:53-72

Mc Ginnity PM, Mills P, Roche W, Müller M (2005) A desk study to determine a methodology for the monitoring of the 'morphological conditions' of Irish Rivers. Final Report. Environmental RTDI Programme 2000-2006. Central Fisheries Board - Compass Informatics - EPA

Maine Department of Environmental Protection (2009) Stream Survey Manual. Volume I and II (and Appendices). Maine Stream Team Program of the Maine Department of Environmental Protection

Meile T, Boillat IL, Schleiss AJ (2011) Hydropeaking indicators for characerization of the Upper-Rhone River in Switzerland. Aquatic Science 73:171-182.

Ministry of the Environment (1999) Revised Stormwater Management Guidelines Draft Report. Ontario Ministry of the Environment. In: Central Lake Ontario Conservation (2011): Black/Harmony/Farewell Creek Watershed. Existing conditions report. Chapter 13 - Fluvial Geomorphology. Durham Region

Minnesota Pollution Control Agency (2002): Physical habitat and water chemistry assessment protocol for wadeable stream monitoring sites. Minnesota Pollution Control Agency, St. Paul

Muhar S, Jungwirth M (1998) Habitat intgegrity of running waters - assessment criteria and their biological relevance. Hydrobiologia 386:195-202. In: Mc Ginnity PM, Mills P, Roche W, Müller M (2005) A desk study to determine a methodology for the monitoring of the 'morphological conditions' of Irish Rivers. Final Report. Environmental RTDI Programme 2000-2006. Central Fisheries Board - Compass Informatics - EPA

Mühlmann H (2010) Leitfaden zur zustandserhebung in fliessgewässern Hydromorphologie. Bundesministerium für Land- und Forstwirtschaft, Umwelt und Wasserwirtschaft (Wien). http://wisa.lebensministerium.at/article/articleview/81530/1/29401/ 
Munné A, Prat N (1998) QBR: Un índice rápido para la evaluación de la calidad de los ecosistemas de ribera. Tecnología del Agua 175:20-37

Munné A, Prat N, Sola C, Bonada N, Rieradevell M (2003) A simple field method for assessing the ecological quality of riparian habitat in rivers and streams: QBR index. Aquatic conserv: Mar Freshw Ecosyst 13: 147-163

Munné A, Solà C, Pagés J (2006) HIDRI: Protocolo para la valoración de la calidad hidromorfológica de los ríos. Agència Catalana de l'Aigua, Barcelona

Murphy M, Toland M (2012) River Hydromorphology Assessment Technique (RHAT). Training guide. Northern Ireland Environment Agency, Department of the Environment, Version 2012

National Environmental Research Institute (1999) National Physical Habitat Index. In: Mc Ginnity PM, Mills P, Roche W, Müller M (2005) A desk study to determine a methodology for the monitoring of the 'morphological conditions' of Irish Rivers. Final Report. Environmental RTDI Programme 2000-2006. Central Fisheries Board - Compass Informatics - EPA

Newson MD, Large ARG (2006) 'Natural' rivers, 'hydromorphological quality' and river restoration: a challenging new agenda for applied fluvial geomorphology. Earth Surf Process Landforms 31:1606-1624

Ohio Environmental Protection Agency (2002) Field evaluation manual for Ohio's primary headwater habitat streams. Final Version 1.0. Division of Surface Water, Ohio Environmental Protection Agency, Columbus, Ohio. In: Kasich J, Taylor M, Nally S (2012) Field Evaluation Manual for Ohio's Primary Headwater Habitat Streams, Version 3.0. Ohio, US

Oliveira SV, Cortes RMV (2005) A biologically relevant habitat condition index for streams in northern Portugal. Aquatic Conserv: Mar Freshw Ecosyst 15(2):189210

Ollero A, Ballarín D, Díaz E, Mora D, Sánchez M, Acín V, Echeverría MT, Granado D, Ibisate A, Sánchez L, Sánchez N (2007) Un indice hidrogeomorfologico (IHG) para la evaluacion del estado ecologico de sistemas fluviales. Geographicalia 52:113-141

ONEMA (2010) Des étapes et des outils... Les outils de connaissance de l'hydromorphologie des cours d'eau français. Restauration physique des cours d'eau - Connaissance

Overton CK, Wollrab SP, Roberts CB, Radko MA (1997) Fish and Fish Habitat Standard Inventory Procedures handbook. United States Department of Agriculture, Forest Service

Oregon Watershed Enhancement Board (2000): Oregon Watershed Assessment Manual. http://www.oregon.gov/OWEB/pages/docs/pubs/or_wsassess manuals.aspx

Paetzold A, Yoshimura C, Tockner K (2008) Riparian arthropod responses to flow regulation and river channelization. Journal of Applied Ecology 45:894-903.

Pardo I, Álvarez M, Casas J, Moreno JL, Vivas S, Bonada N, Alba-Tercedor J, Jáimez-Cuéllar P, Moyà G, Prat N, Robles S, Suárez ML, Toro M, Vidal- 
Abarca MR (2002) El hábitat de los ríos mediterráneos. Diseño de un índice de diversidad de hábitat. Limnetica 21(3-4):115-133

Parsons M, Thoms MC, Norris RH (2004) Development of a standardised approach to river habitat assessment in Australia. Env Monit Assess 98:109-130. In: Mc Ginnity PM, Mills P, Roche W, Müller M (2005) A desk study to determine a methodology for the monitoring of the 'morphological conditions' of Irish Rivers. Final Report. Environmental RTDI Programme 2000-2006. Central Fisheries Board - Compass Informatics - EPA

Pedersen ML, Baattrup-Pedersen A (2003) Økologisk overvågning i vandløb og på vandløbsnære arealer under NOVANA 2004-2009. Danmarks Miljøundersøgelser. Teknisk Anvisning fra DMU nr. 21. In: National Environmental Research Institute and Slovak Hydrometeorological Institute (2004) Establishment of the Protocol on Monitoring and Assessment of the Hydromorphological Elements (Slovakia). Final Report

Person E, Peter A (2012) Influence of hydropeaking on brown trout habitat. Conference paper $9^{\text {th }}$ International Symposium on Ecohydraulics, $17^{\text {th }}-21^{\text {st }}$ September 2012

Petersen RC (1992) The RCE: a Riparian, Channel, and Environmental Inventory for small streams in the agricultural landscape. Freshwater Biology 27(2):295-306. doi:10.1111/j.1365-2427.1992.tb00541.x

Plafkin JL, Barbour MT, Porter KD, Gross SK, Hughes RM (1989) Rapid bioassessment protocols for use in streams and rivers-Benthic macroinvertebrates and fish. USEPA/440/4-89-001. US Environmental Protection Agency. Washington, D.C. In: Barbour MT, Gerritsen J, Snyder BD, Stribling JB (1999) Rapid Bioassessment Protocols for use in streams and wadeable rivers: periphyton, benthic macroinvertebrates, and fish. Second edition. EPA 841-B-99-002 U.S.

Platts WS, Megahan WF, Minshall GW (1983) Methods for evaluating stream, riparian, and biotic conditions. US Department of Agriculture, Forest Service, Intermountain Forest and Range Experiment Station. Ogden, UT

Poff NL, Allan JD, Palmer MA, Hart DD, Richter BD, Arthington AH, Rogers KH, Meyer JL, Stanford JA (2003) River flows and water wars: emerging science for environmental decision making. Front Ecol Environ 1:298-306

Poff NL, Zimmerman JKH (2010) Ecological responses to altered flow regimes: a literature review to inform the science and management of environmental flow. Freshwater biology 55:147-170

Prichard D, Barrett H, Cagney J, Clark R, Fogg J, Gebhardt K, Hansen PL, Mitchell B, Tippy D (1998) Riparian area management: Process for assessing proper functioning condition. Technical Reference 1737-9, BLM/SC/ST9/003+1737+REV95+REV98. Bureau of Land Management, Denver

Rankin ET (1989) The Qualitative Habitat Evaluation Index (QHEI): Rationale, methods, and application. Div. Water Qual. Plan. \& Assess., Ecol. Assess. Sect., Columbus, Ohio. In: Taft B, Koncelik JP (2006): Methods for Assessing Habitat in Flowing Waters: Using the Qualitative Habitat Evaluation Index (QHEI). Ohio EPA 
Raven PJ, Fox P, Everard M, Holmes NTH, Dawson FH (1997) River habitat survey: A new system for classifying rivers according to their habitat quality. Freshwater Quality: Defining the Indefinable? In: Raven PJ, Holmes NTH, Charrier P, Dawson FH, Naura M, Boon PJ (2002) Towards a harmonized approach for hydromorphological assessment of rivers in Europe: a qualitative comparison of three survey methods. Aquatic Conserv: Mar Freshw Ecosyst 12(4):405-424

Raven PJ, Holmes NTH, Charrier P, Dawson FH, Naura M, Boon PJ (2002) Towards a harmonized approach for hydromorphological assessment of rivers in Europe: a qualitative comparison of three survey methods. Aquatic Conserv: Mar Freshw Ecosyst 12(4):405-424

Raven P., Holmes N., Pádua J., Ferreira J., Hughes S., Baker L., Taylor L., Seager K. (2009). River Habitat Survey in Southern Portugal. Results from 2009. Environment Agency, Bristol

Richter BD, Baumgartner JV, Powell J, Braun DP (1996) A method for assessing hydrologic alteration within ecosystems. Conservation Biology 10(4):11631174

Rinaldi M, Surian N, Comiti F, Bussettini M (2013a) A method for the assessment and analysis of the hydromorphological condition of Italian streams: The Morphological Quality Index (MQI). Geomorphology 180-181:96-108. doi: 10.1016/j.geomorph.2012.09.009

Rinaldi M, Belletti B, Van de Bund W, Bertoldi W, Gurnell A, Buijse T, Mosselman E (2013b). Review on eco-hydromorphological methods. Deliverable 1.1, REFORM (REstoring rivers FOR effective catchment Management), Project funded by the European Commission within the 7th Framework Programme (2007 - 2013), Topic ENV.2011.2.1.2-1 Hydromorphology and ecological objectives of WFD, Grant Agreement 282656

Rinaldi M, Wyzga B, Dufour S, Bertoldi W, Gurnell AM (2013c) River Processes and Implications for Fluvial Ecogeomorphology: A European Perspective. In: Schroder J.F. (ed.) Treatise in Geomorphology 12(4):37-52.

Rosgen DL (1996) Applied River Morphology. Wildland Hydrology, Pagosa Springs, CO. In: Rosgen D (2006) The Natural Channel Design Method for River Restoration. Wildland Hydrology

Rosgen DL (2006) A Watershed Assessment for River Stability and Sediment Supply (WARSSS). Wildland Hydrology Books, Fort Collins, CO. http://www.epa.gov/warsss/

Rowntree KM, Wadeson RA (2000) Field manual for channel classification and condition assessment Institute for Water Quality Studies, Department of Water Affairs and Forestry, Pretoria, South Africa

Saint-Jaques N, Richard Y (1998): Développement d'un indice de qualité de la bande riveraine : application à la rivière Chaudière et mise en relation avec l'intégrité biotique du milieu aquatique. In: Le bassin de la rivière Chaudière: qualité de la bande riveraine. Direction des écosystèmes aquatiques - Ministère de l'Environnement et de la faune (Quebec), 6.1-6.41. 
Scheifhacken N, Haase U, Gram-Radu L, Kozovyi R, Berendonk TU (20121) How to assess hydromorphology? A comparison of Ukrainian and German approaches. Environ Earth Sci 65:1483-1499. doi:10.1007/s12665-011-1218-2

Schneiders A, Verhaert E, Blust GD, Wils C, Nervoets L, Verheyen R (1993) Towards an ecological assessment of watercourses. Journal of Aquatic Ecosystem Health 2:29-38. In: Mc Ginnity PM, Mills P, Roche W, Müller M (2005) A desk study to determine a methodology for the monitoring of the 'morphological conditions' of Irish Rivers. Final Report. Environmental RTDI Programme 2000-2006. Central Fisheries Board - Compass Informatics - EPA

Schumm SA, Harvey MD, Watson CC (1984) Incised Channels: Morphology, Dynamics and Control. Water Resources Publications, Littleton, Colorado. In: Darby SE, Simon A (eds) (1999) Incised River Channels: processes, forms, engineering and management. John Wiley \& Sons 2:19-33.

Sear DA, Hill CT, Downes RHE (2008) Geomorphological assessment of riverine SSSIs for the strategic planning of physical restoration. Report NERR013. Natural England Research

Shiau J-T, Wu F-C (2008) A Histogram Matching Approach for assessment of flow regime alteration: application to environmental flow optimization. River Res Applic 24(7):914-928

Siligardi M, Bernabei S, Cappeletti C, Chierici E, Ciutti F, Egaddi F, Franceschini A, Maiolini B, Mancini L, Minciardi MR, Monauni C, Rossi GL, Sansoni G, Spaggiari R, Zanetti M (2002) I.F.F. Indice di funzionalità fluviale. Manuale ANPA

Simon A, Hupp CR (1986) Channel Evolution in Modified Tennessee Channels. Proceedings of the Fourth Interagency Sedimentation Conference, Las Vegas, Nevada. In: Darby SE, Simon A (eds) (1999) Incised River Channels: processes, forms, engineering and management. John Wiley \& Sons, 1:3-18.

Simon A, Downs PW (1995) An interdisciplinary approach to evaluation of potential instability in alluvial channels. Geomorphology 12(3):215-232. In: Heeren DM, Mittelstet AR, Fox GA, Storm DE, Al-Madhhachi AT, Midgley TL, Stringer AF, Stunkel KB, Tejral RD (2012) Using Rapid Geomorphic Assessments to assess streambank stability in Oklahoma Ozark streams. American Society of Agricultural and Biological Engineers 55(3):957-968

Skriver J, Riis T, Carl J, Baattrup-Pedresen A, Friberg N, Ernst ME, Frandsen SB, Sode A, Wiberg-Larsen P (1999) Biologisk vandløbskvalitet (DVFI). Udvidet biologisk program. NOVA 2003. Afdeling for Vandløbsøkologi og Afdeling for Sø- og Fjordøkologi. In: Mc Ginnity PM, Mills P, Roche W, Müller M (2005) A desk study to determine a methodology for the monitoring of the 'morphological conditions' of Irish Rivers. Final Report. Environmental RTDI Programme 2000-2006. Central Fisheries Board - Compass Informatics - EPA

Smith D, Ammann A, Bartoldus C, Brinson MM (1995) An Approach for Assessing Wetland Functions Using Hydrogeomorphic Classification, Reference Wetlands, and Functional Indices. vol Wetlands Research Program Technical Report WRP-DE-9. US Army Corps of Engineers Waterways Experiment Station 
Spiegler A, Godina, Grass, Imhoff, Katzmann, Nachtnebel, Ohnmatch, Pelikan, Sabata (1989): Strukturökologische Methode zur Bestandsaufnahme und Bewertung von Fließgewässern. Planungen und Untersuchungen.

Bundesministerium für Land- und Forstwirtschaft, Wasserwirtschaftskataster. Wien. In: Mc Ginnity PM, Mills P, Roche W, Müller M (2005) A desk study to determine a methodology for the monitoring of the 'morphological conditions' of Irish Rivers. Final Report. Environmental RTDI Programme 2000-2006. Central Fisheries Board - Compass Informatics - EPA

Starr RR, Mc Candless T (2001) Stream and riparian habitats rapid assessment protocol. Chesapeake Bay Field Office, U.S. Fish and Wildlife Service, Annapolis, MD. In: Somerville DE, Pruitt BA (2004) Physical Stream Assessment: A Review of Selected Protocols for Use in the Clean Water Act Section 404 Program. vol 3W-0503-NATX. US Environmental Protection Agency, Office of Wetlands, Oceans, and Watersheds, Wetlands Division

Starr RR (2009) Stream Assessment Protocol. Anne Arundel County, Maryland - US Fish \& Wildlife Service

Stranko S, Boward D, Kilian J, Becker A, Ashton M, Schenk A, Gauza R, RoseberryLincoln A, Kazyak P (2010) Maryland Biological Stream Survey, Round Three Field Sampling Manual. Revised version. Maryland Department of Natural Resources

Tavzes B, Urbanic G (2009) New indices for assessment of hydromorphological alteration of rivers and their evaluation with benthic invertebrate communities; Alpine case study. Review of Hydrobiology 2:133-161

The Nature Conservancy (2009) Indicators of Hydrologic Alteration Version 7.1. User's Manual

Thorne CR (1998) Geomorphological stream reconnaissance handbook. Wiley Chichester

Tickner D, Armitage PD, Bickerton MA, Hall KA (2000) Assessing stream quality using information on mesohabitat distribution and character. Aquatic Conserv: Mar Freshw Ecosyst 10(3):179-196

Tockner K, Ward JV (1999) Biodiversity along riparian corridors. Large Rivers 11(3). Arch. Hydrobiol. Suppl. 115(3):293-310

UK Technical Advisory Group on the WFD (2008) UK Environmental Standards and Conditions (Phase 1) - Final. Vol. SR1-2006

US Department of Agriculture (2009) Stream Visual Assessment Protocol Version 2, vol. Subpart B - Conservation Planning. USDA Natural Resources Conservation Service

US Environmental Protection Agency (1997) Volunteer Stream Monitoring: A Methods Manual. In: Mc Ginnity PM, Mills P, Roche W, Müller M (2005) A desk study to determine a methodology for the monitoring of the 'morphological conditions' of Irish Rivers. Final Report. Environmental RTDI Programme 2000-2006. Central Fisheries Board - Compass Informatics - EPA 
US Environmental Protection Agency (2004) Wadeable Streams Assessment (WASss): Field operations manual. EPA841- B-04-004. Office of Water and Office of Research and Development, Washington, DC

US Forest Service (2006): Stream Inventory Handbook - Level I \& II. Vol. 2.6. US Forest Service, Pacific Northwest Region

Valette L, Chandesris A, Malavoi JR, Suchon Y, Willet B (2010) Protocole AURAHCE AUdit RApide de l'Hydromorphologie des Cours d'Eau. Méthode de recueil d'informations complémentaires à SYRAH-CE sur le terrain, Pôle hydroécologie des cours d'eau - Onema/Cemagref

Vermont Agency of Natural Resources (2010) Vermont Stream Geomorphic Assessment. Appendix A - Field Forms. Waterbury http://www.vtwaterquality.org/rivers/htm/rv_geoassesspro.htm

Vaughan IP, Diamond M, Gurnell AM, Hall KA, Jenkins A, Milner NJ, Naylor LA, Sear DA, Woodward G, Ormerod SJ (2009) Integrating ecology with hydromorphology: a priority for river science and management. Aquatic Conserv: Mar Freshw Ecosyst 19:113-125

Ward TA, Tate KW, Atwill ER (2003) Visual Assessment of Riparian Health. Vol ANR Publication 8089, Rangeland Monitoring Series. University of California

Weiss A, Matouskova M, Matschullat J (2008) Hydromorphological assessment within the EU-Water Framework Directive - trans-boundary cooperation and application to different water basins. Hydrobiologia 603:53-72

Werth W (1987) Ökomorphologische Gewässerbewertung in Oberösterreich (Gewässerzustandkartierungen). Eco-morphological classification of channels in Upper Austria. In: Oesterreichische Wasserwirtschaft 39 (5/6). Wien (Springer): 121-128. In: Mc Ginnity PM, Mills P, Roche W, Müller M (2005) A desk study to determine a methodology for the monitoring of the 'morphological conditions' of Irish Rivers. Final Report. Environmental RTDI Programme 2000-2006. Central Fisheries Board - Compass Informatics - EPA

Wilhelm J, Allan J, Wessell K, Merritt R, Cummins K (2005) Habitat Assessment of Non-Wadeable Rivers in Michigan. Environmental Management 36:592-609. doi:10.1007/s00267-004-0141-7

Wils C, Schneiders A, Bervoets L, Nagels A, Weiss L, Verheyen RF (1994) Assessment of the ecological value of rivers in Flanders (Belgium). Water Science and Technology 30(10): 37-47. In: Goethals P, De Pauw N (2001) Development of a concept for integrated ecological river assessment in Flanders, Belgium. Journal of Limnology 60(1):7-16

Winward AF (2000) Monitoring the Vegetation Resources in Riparian Areas. General Technical Report RMRS-GTR-47. US Department of Agriculture

Wyżga B, Amirowicz A, Radecki-Pawlik A, Zawiejska J (2009) Hydromorphological conditions, potential fish habitats and the fish community in a mountain river subjected to variable human impacts, the Czarny Dunajec, Polish Carpathians. River Res Applic 25(5):517-536

Xia T, Zhu W, Xin P, Li L (2010) Assessment of urban stream morphology: an integrated index and modelling system. Environ Monit Assess 167(1-4):447-460 
Yetman KT (2001) Stream corridor assessment survey. Survey protocols. Watershed Restoration Division Chesapeake \& Coastal Watershed Services Maryland Maryland Dept. of Natural Resources

Zolezzi G, Bellin A, Bruno MC, Maiolini B, Siviglia A (2009) Assessing hydrological alterations at multiple temporal scales: Adige River, Italy. Water Resources Research 45(12):W12421. doi:10.1029/2008WR007266. 
Table 1 Summary of hydromorphological assessment methods included in this review with percentage coverage regarding method characteristics $(\mathrm{Ch})$, recorded features (Fe) and river processes ( $\mathrm{Rp}$ ) (for details see Table 2). Method are listed chronologically within each category: $\mathrm{PH}=$ physical habitat assessment; $\mathrm{RH}=$ riparian habitat assessment; $\mathrm{M}=$ morphological assessment; HRA = hydrological regime alteration assessment. a.: not applicable.

\begin{tabular}{|c|c|c|c|c|c|c|c|c|}
\hline & Category & Year & Country & Acronym & Key reference & Ch & $\mathrm{Fe}$ & $\mathbf{R p}$ \\
\hline 1 & $\mathrm{PH}$ & 1983 & US & MESC & Platts et al. (1983) & 47 & 56 & 33 \\
\hline 2 & $\mathrm{PH}$ & 1987 & Austria & Werth & Werth (1987) & 59 & 48 & 17 \\
\hline 3 & $\mathrm{PH}$ & 1989 & Austria & WatercSt & Spiegler et al. (1989) & 53 & 59 & 17 \\
\hline 4 & $\mathrm{PH}$ & 1989 & US & QHEI & Rankin (1989) & 59 & 63 & 33 \\
\hline 5 & $\mathrm{PH}$ & 1992 & Sweden & $\mathrm{RCE}$ & Petersen (1992) & 47 & 33 & 33 \\
\hline 6 & $\mathrm{PH}$ & 1993 & Australia & SRS & Anderson (1993) & 59 & 41 & 33 \\
\hline 7 & $\mathrm{PH}$ & 1993 & Belgium & SEvalW & Schneiders et al. (1993) & 47 & 33 & 17 \\
\hline 8 & $\mathrm{PH}$ & 1994 & Belgium & SK & Wils et al. (1994) & 35 & 11 & 0 \\
\hline 9 & $\mathrm{PH}$ & 1996 & Austria & GEBD (RSR) & Buhmann and Hutter (1996) & 59 & 56 & 17 \\
\hline 10 & $\mathrm{PH}$ & 1996 & France & Qualphy & Denortier and Goetghebeur (1996) & 59 & 63 & 33 \\
\hline 11 & $\mathrm{PH}$ & 1996 & US & RSAT & Galli (1996) & 41 & 41 & 17 \\
\hline 12 & $\mathrm{PH}$ & 1997 & England & RHS & Raven et al. (1997) & 53 & 67 & 50 \\
\hline 13 & $\mathrm{PH}$ & 1997 & Poland & EcomorphEval & Ilnicki and Lewandowski (1997) & 47 & 41 & 33 \\
\hline 14 & $\mathrm{PH}$ & 1997 & US & FFHSIP & Overton et al. (1997) & 41 & 33 & 17 \\
\hline 15 & $\mathrm{PH}$ & 1997 & US & VSMM & US Env. Protection Agency (1997) & 59 & 52 & 33 \\
\hline 16 & $\mathrm{PH}$ & 1998 & Austria & AssRivSt & Muhar and Jungwirth (1998) & 59 & 67 & 50 \\
\hline 17 & $\mathrm{PH}$ & 1998 & Austria & RATyrol & BUWAL (1998) & 41 & 26 & 17 \\
\hline 18 & $\mathrm{PH}$ & 1998 & Denmark & DSFI & Danish Env. Protection Agency (1998) & 35 & 7 & 0 \\
\hline 19 & $\mathrm{PH}$ & 1998 & France & SEQ-P & Agences de L'Eau (1998) & 59 & 63 & 33 \\
\hline 20 & $\mathrm{PH}$ & 1998 & Switzerland & ModConc & Liechti et al. (1998) & 41 & 37 & 33 \\
\hline 21 & $\mathrm{PH}$ & 1998 & US & MCSH (NAWQA) & Fitzpatrick et al. (1998) & 47 & 37 & 0 \\
\hline 22 & $\mathrm{PH}$ & 1998 & US & RHVSA-EMAP & Lazorchak et al. (1998) & 41 & 37 & 0 \\
\hline 23 & $\mathrm{PH}$ & 1999 & Australia & ISC & Ladson et al. (1999) & 65 & 30 & 33 \\
\hline 24 & $\mathrm{PH}$ & 1999 & Denmark & Aarhus & Kaarup (1999) & 47 & 18 & 17 \\
\hline 25 & $\mathrm{PH}$ & 1999 & Denmark & NPHI & National Env. Research Institute (1999) & 47 & 37 & 0 \\
\hline 26 & $\mathrm{PH}$ & 1999 & Denmark & PhysSC & Skriver et al. (1999) & 41 & 41 & 0 \\
\hline 27 & $\mathrm{PH}$ & 1999 & US & PHC (EMAP) & Kaufmann et al. (1999) & 41 & 41 & 0 \\
\hline 28 & $\mathrm{PH}$ & 1999 & US & RBP & Plafkin et al. (1989); Barbour et al. (1999) & 59 & 56 & 33 \\
\hline 29 & $\mathrm{PH}$ & 2000 & Australia & HPM & Davies et al. (2000) & 59 & 48 & 17 \\
\hline 30 & $\mathrm{PH}$ & 2000 & England & MesoH & Tickner et al. (2000) & 41 & 11 & 0 \\
\hline 31 & $\mathrm{PH}$ & 2000 & Germany & LAWA-FS-MToL & LAWA (2000) & 59 & 48 & 50 \\
\hline 32 & $\mathrm{PH}$ & 2000 & US & WCE & Oregon Watersh. Enhanc. Board (2000) & 71 & 52 & 33 \\
\hline 33 & $\mathrm{PH}$ & 2001 & Austria & NÖMORPH & Freiland Umeltconsulting $(2001 \mathrm{a}, \mathrm{b})$ & 59 & 41 & 17 \\
\hline 34 & $\mathrm{PH}$ & 2001 & Germany & $\mathrm{BfG}-\mathrm{WW}$ & Bundesanstalt für Gewässerkunde (2001) & 47 & 56 & 50 \\
\hline 35 & $\mathrm{PH}$ & 2001 & US & SCA & Yetman (2001) & 47 & 48 & 50 \\
\hline 36 & $\mathrm{PH}$ & 2001 & US & SRHRAP & Starr and McCandless (2001) & 41 & 41 & 33 \\
\hline 37 & $\mathrm{PH}$ & 2002 & Germany & LAWA-FS-SToL & LAWA (2002a) & 59 & 52 & 50 \\
\hline 38 & $\mathrm{PH}$ & 2002 & Germany & LAWA-OS & LAWA (2002a, b) & 53 & 37 & 50 \\
\hline
\end{tabular}




\begin{tabular}{|c|c|c|c|c|c|c|c|c|}
\hline 39 & $\mathrm{PH}$ & 2002 & Italy & IFF & Siligardi et al. (2002) & 59 & 37 & 17 \\
\hline 40 & $\mathrm{PH}$ & 2002 & Spain & IHF & Pardo et al. (2002) & 41 & 18 & 0 \\
\hline 41 & $\mathrm{PH}$ & 2002 & Sweden & BiotopeMap & Hallde'n et al. (2002) & 65 & 44 & 17 \\
\hline 42 & $\mathrm{PH}$ & 2002 & US & HHEI & Ohio Env. Protection Agency (2002) & 59 & 30 & 0 \\
\hline 43 & $\mathrm{PH}$ & 2002 & US & MinHWCP & Minnesota Pollution Control Ag. (2002) & 41 & 44 & 17 \\
\hline 44 & $\mathrm{PH}$ & 2003 & Denmark & DHQI & Pedersen and Baattrup-Pedersen (2003) & 71 & 41 & 17 \\
\hline 45 & $\mathrm{PH}$ & 2003 & England & GeoRHS & Environment Agency (2003) & 59 & 48 & 67 \\
\hline 46 & $\mathrm{PH}$ & 2003 & US & MNHWA & Crowe and Kudray (2003) & 47 & 26 & 33 \\
\hline 47 & $\mathrm{PH}$ & 2004 & Australia & AusRivAs-PAP & Parsons et al. (2004) & 65 & 70 & 50 \\
\hline 48 & $\mathrm{PH}$ & 2004 & England & URS & Davenport et al. (2004) & 53 & 56 & 50 \\
\hline 49 & $\mathrm{PH}$ & 2004 & Germany & GSI & Feld (2004) & 59 & 52 & 17 \\
\hline 50 & $\mathrm{PH}$ & 2004 & US & BURP & Idaho Dep. Env. Quality (2004) & 53 & 37 & 17 \\
\hline 51 & $\mathrm{PH}$ & 2004 & US & SEvalAH & Kansas Dep. of Widelife and Parks (2004) & 53 & 37 & 33 \\
\hline 52 & $\mathrm{PH}$ & 2004 & US & VSGA & Vermont Ag. of Natural Resources (2004) & 53 & 63 & 67 \\
\hline 53 & $\mathrm{PH}$ & 2004 & US & WSAss & US Env. Protecion Agency (2004) & 47 & 44 & 33 \\
\hline 54 & $\mathrm{PH}$ & 2005 & Italy & CARAVAGGIO & Buffagni et al. (2005) & 59 & 70 & 50 \\
\hline 55 & $\mathrm{PH}$ & 2005 & Portugal & $\mathrm{HCI}$ & Oliveira and Cortes (2005) & 53 & 26 & 0 \\
\hline 56 & $\mathrm{PH}$ & 2005 & US & NWHI & Wilhelm et al. (2005) & 41 & 22 & 17 \\
\hline 57 & $\mathrm{PH}$ & 2006 & Czech Rep. & EcoRivHab & Matoušková (2006) & 65 & 52 & 33 \\
\hline 58 & $\mathrm{PH}$ & 2006 & Spain & HIDRI & Munné et al. (2006) & 71 & 59 & 17 \\
\hline 59 & $\mathrm{PH}$ & 2006 & US & $\mathrm{SIH}$ & US Forest Service (2006) & 53 & 44 & 50 \\
\hline 60 & $\mathrm{PH}$ & 2007 & Netherlands & Handboek HYMO & Dam et al. (2007) & 53 & 41 & 67 \\
\hline 61 & $\mathrm{PH}$ & 2007 & Slovakia & $\mathrm{HAP}-\mathrm{SR}$ & Lehotský and Grešková (2007) & 59 & 63 & 67 \\
\hline 62 & $\mathrm{PH}$ & 2008 & South Africa & IHI & Kleynhans et al. (2008) & 53 & 41 & 33 \\
\hline 63 & $\mathrm{PH}$ & 2009 & $\mathrm{NZ}$ & SHAP & Harding et al. (2009) & 53 & 59 & 17 \\
\hline 64 & $\mathrm{PH}$ & 2009 & Poland & MHR & Ilnicki et al. (2009) & 59 & 56 & 33 \\
\hline 65 & $\mathrm{PH}$ & 2009 & Slovenia & SI_HM & Tavzes and Urbanic (2009) & 53 & 67 & 50 \\
\hline 66 & $\mathrm{PH}$ & 2009 & US & SCS-SH & Maine Dep. of Env. Protection (2009) & 59 & 48 & 50 \\
\hline 67 & $\mathrm{PH}$ & 2009 & US & SVAP & US Dep. of Agricolture (2009) & 53 & 59 & 67 \\
\hline 68 & $\mathrm{PH}$ & 2010 & Austria & HYMO & Mühlmann (2010) & 47 & 41 & 50 \\
\hline 69 & $\mathrm{PH}$ & 2010 & China & USM & Xia et al. (2010) & 41 & 44 & 50 \\
\hline 70 & $\mathrm{PH}$ & 2010 & France & CarHyCE & ONEMA (2010) & 35 & 44 & 33 \\
\hline 71 & $\mathrm{PH}$ & 2010 & US & MBSS & Stranko et al. (2010) & 47 & 52 & 17 \\
\hline 72 & $\mathrm{PH}$ & 2011 & Ukraine & UA-FS & Scheifhacken et al. (2011) & 47 & 48 & 17 \\
\hline 73 & $\mathrm{PH}$ & 2012 & Ireland & RHAT & Murphy and Toland (2012) & 65 & 67 & 67 \\
\hline 74 & RH & 1995 & US & HGM & Smith et al. (1995) & 35 & 7 & 17 \\
\hline 75 & RH & 1998 & Italy & BSI \& WSI & Braioni and Penna (1998) & 59 & 67 & 0 \\
\hline 76 & RH & 1998 & Quebec & IQBR & Saint-Jacques and Richard (1998) & 35 & 22 & 0 \\
\hline 77 & $\mathrm{RH}$ & 1998 & Spain & QBR & Munné and Prat (1998); Munné et al. (2006) & 47 & 33 & 17 \\
\hline 78 & RH & 1998 & US & $\mathrm{PFC}$ & Prichard et al. (1998) & 29 & 41 & 50 \\
\hline 79 & RH & 2000 & US & RWA & Oregon Watersh. Enhanc. Board (2000) & 47 & 22 & 17 \\
\hline 80 & $\mathrm{RH}$ & 2000 & US & VRRA & Winward (2000) & 41 & 15 & 17 \\
\hline 81 & RH & 2003 & US & VARH & Ward et al. (2003) & 35 & 41 & 33 \\
\hline 82 & $\mathrm{RH}$ & 2005 & Australia & RARC & Jansen et al. (2005) & 35 & 22 & 0 \\
\hline 83 & RH & 2005 & Australia & TRARC & Dixon et al. (2005) & 35 & 22 & 0 \\
\hline
\end{tabular}




\begin{tabular}{|c|c|c|c|c|c|c|c|c|}
\hline 84 & RH & 2006 & Spain & IVF & Munné et al. (2006) & 47 & 41 & 0 \\
\hline 85 & RH & 2007 & South Africa & VEGRAI & Kleynhans et al. (2007) & 47 & 30 & 0 \\
\hline 86 & RH & 2010 & Spain & RFV & Magdaleno et al. (2010) & 47 & 22 & 0 \\
\hline 87 & RH & 2011 & Spain & RQI & González DT and García DJ (2011) & 47 & 63 & 50 \\
\hline 88 & RH & 2012 & Australia & RVC_RCI & Healey et al. (2012) & 47 & 22 & 17 \\
\hline 89 & M & $1984-86$ & US & CEMs & Schumm et al. (1984); Simon and Hupp (1986) & 29 & 29 & 67 \\
\hline 90 & M & 1994 & US & SCRS & Harrelson et al. (1994) & 41 & 48 & 33 \\
\hline 91 & M & 1995 & US & RGAs & Ministry of Env. (1999); Simon and Downs (1995) & 59 & 41 & 33 \\
\hline 92 & M & 1996 & US & NCD & Rosgen (1996) & 53 & 52 & 33 \\
\hline 93 & M & 1998 & England & FA & Environment Agency (1998) & 65 & 81 & 83 \\
\hline 94 & M & 1998 & England & SRH & Thorne (1998) & 53 & 70 & 50 \\
\hline 95 & M & 2000 & South Africa & GI & Rowntree and Wadeson (2000) & 71 & 56 & 33 \\
\hline 96 & M & 2000 & US & CMA & Oregon Watersh. Enhanc. Board (2000) & 65 & 26 & 33 \\
\hline 97 & M & 2005 & Australia & RSF & Brierely and Fryirs (2005) & 65 & 56 & 67 \\
\hline 98 & M & 2005 & South Africa & GAI & Kleynhans et al. (2005) & 53 & 44 & 83 \\
\hline 99 & M & 2006 & Spain & HIDRI-P1 & Munné et al. (2006) & 41 & 11 & 0 \\
\hline 100 & M & 2006 & US & WARSSS & Rosgen (2006) & 53 & 56 & 67 \\
\hline 101 & M & 2007 & Czech Republic & HEM & Langhammer (2007) & 71 & 48 & 50 \\
\hline 102 & M & 2007 & Spain & IHG & Ollero et al. (2007) & 59 & 63 & 83 \\
\hline 103 & M & 2008 & England & GAP & Sear et al. (2008) & 59 & 81 & 83 \\
\hline 104 & M & 2008 & France & SYRAH-CE & Chandesris et al. (2008) & 47 & 37 & 100 \\
\hline 105 & M & 2008 & Scotland & MImAS & UK Technical Advisory Group (2008) & 59 & 52 & 67 \\
\hline 106 & M & 2009 & Poland & RHQ & Wyżga et al. (2009) & 65 & 56 & 83 \\
\hline 107 & M & 2009 & US & SAP & Starr (2009) & 53 & 48 & 50 \\
\hline 108 & M & 2009 & US & SCS-RGA & Maine Dep. of Env. Protection (2009) & 65 & 22 & 50 \\
\hline 109 & M & 2010 & France & AURAH-CE & Valette et al. (2010) & 41 & 18 & 17 \\
\hline 110 & M & 2013 & Italy & MQI & Rinaldi et al. (2013) & 65 & 59 & 83 \\
\hline 111 & HRA & 1998 & US & RVA & Richter et al. (1996) & 32 & 54 & n.a. \\
\hline 112 & HRA & 2000 & US & $\mathrm{HCA}$ & Oregon Watersh. Enhanc. Board (2000) & 36 & 41 & n.a. \\
\hline 113 & HRA & 2005 & Scotland & DHRAM & Black et al. (2005) & 46 & 54 & n.a. \\
\hline 114 & HRA & 2005 & South Africa & HAI & Kleynhans et al. (2005) & 39 & 41 & n.a. \\
\hline 115 & HRA & 2006 & Spain & QM-HIDRI & Munné et al. (2006) & 39 & 18 & n.a. \\
\hline 116 & HRA & 2006 & US & HIT & Henriksen et al. (2006) & 29 & 50 & n.a. \\
\hline 117 & HRA & 2008 & Taiwan & HMA & Shiau and $\mathrm{Wu}(2008)$ & 46 & 54 & n.a. \\
\hline 118 & HRA & 2009 & US & IHA & The Nature Conservancy (2009) & 25 & 59 & n.a. \\
\hline 119 & HRA & 2010 & Spain & IAHRIS & Martínez SM and Fernández Yuste (2010) & 39 & 54 & n.a. \\
\hline 120 & HRA & 2011 & Italy & IARI & ISPRA (2011) & 57 & 68 & n.a. \\
\hline 121 & HRA & 2012 & Australia & HS_RCI & Healey et al. (2012) & 50 & 54 & n.a. \\
\hline
\end{tabular}


Table 2 Information synthesis for each assessment category (PH, RH, M, HRA). For each category the percentage of methods considering a specific type of characteristic, feature and process is given. Codes in the third column correspond to those reported in Figures 3 and 4. " " " = not analysed

\begin{tabular}{|c|c|c|c|c|c|c|}
\hline $\begin{array}{l}\text { Categories of } \\
\text { information }\end{array}$ & Type & Code & $\begin{array}{l}\text { PH } \\
\text { (73) }\end{array}$ & $\begin{array}{l}\text { RH } \\
\text { (15) }\end{array}$ & $\begin{array}{c}\text { M } \\
(\mathbf{2 2})\end{array}$ & $\begin{array}{c}\text { HRA } \\
\text { (11) }\end{array}$ \\
\hline \multicolumn{3}{|l|}{ (a) Method characteristics } & \multicolumn{4}{|c|}{$\%$} \\
\hline \multirow{5}{*}{$\begin{array}{l}\text { Source of information / } \\
\text { Data collection methods }\end{array}$} & - Map/Remote sensing & $\mathrm{M} / \mathrm{RS}$ & 60 & 33 & 73 & 55 \\
\hline & - Field survey or measurement & FS & 99 & 93 & 91 & 9 \\
\hline & - Rapid field assessment & $\mathrm{RF}$ & 34 & 27 & 9 & l \\
\hline & - Modelling & MO & 10 & 0 & 5 & 91 \\
\hline & - Existing database or data series & $\mathrm{ED}$ & l & l & l & 100 \\
\hline \multirow[t]{7}{*}{ Type of method/assessment } & - Characterization/Inventorying & $\mathrm{CI}$ & 66 & 33 & 50 & 1 \\
\hline & - Assessment by index & IN & 78 & 73 & 59 & l \\
\hline & - General assessment/Design & GA & 6 & 0 & 50 & / \\
\hline & - Simple index & SI & I & / & / & 36 \\
\hline & - Multiple index & MI & I & l & l & 46 \\
\hline & - Modelling status & MS & l & l & l & 18 \\
\hline & - Expert judgment & EJ & l & l & l & 27 \\
\hline \multirow[t]{2}{*}{ River typology } & - No river typology & NT & l & l & l & 64 \\
\hline & - River typology/type & RT & l & l & l & 0 \\
\hline \multirow[t]{3}{*}{ Reference conditions } & - Use of reference conditions & $\mathrm{RC}$ & 58 & 40 & 64 & l \\
\hline & - Known reference conditions & KR & l & l & l & 64 \\
\hline & - Reconstructed reference conditions & $\mathrm{RR}$ & l & l & l & 27 \\
\hline \multirow{10}{*}{$\begin{array}{ll}\text { Spatial } & \text { Longitudinal } \\
\text { scale } & \end{array}$} & - Fixed length & FI & 37 & 33 & 9 & I \\
\hline & - Length vs. width & $\mathrm{CW}$ & 18 & 7 & 14 & l \\
\hline & - Variable length & VA & 47 & 60 & 64 & l \\
\hline & - Channel & $\mathrm{CH}$ & 100 & 53 & 100 & 1 \\
\hline & - Banks/Riparian zone & $\mathrm{B} / \mathrm{RZ}$ & 95 & 93 & 96 & 1 \\
\hline & - Floodplain & FP & 71 & 53 & 86 & l \\
\hline & - Catchment & $\mathrm{CA}$ & l & I & I & 18 \\
\hline & - River & RI & l & l & l & 36 \\
\hline & - Reach & $\mathrm{RE}$ & l & l & l & 91 \\
\hline & - Section & SE & l & l & l & 36 \\
\hline \multirow[t]{7}{*}{ Temporal scale } & - Present (last year) & $\mathrm{P}$ & 100 & 100 & 100 & I \\
\hline & - Recent (1-10 year) & $\mathrm{R}$ & 3 & 7 & 36 & l \\
\hline & - Historical (10-50 year) & $\mathrm{H}$ & 6 & 7 & 46 & l \\
\hline & - Monthly & $\mathrm{M}$ & I & 1 & 1 & 55 \\
\hline & - Daily & $\mathrm{D}$ & l & l & l & 82 \\
\hline & - Hourly & $\mathrm{H}$ & I & I & l & 0 \\
\hline & - Other & $\mathrm{O}$ & l & l & I & 27 \\
\hline \multirow[t]{3}{*}{ Predictive ability } & - Pressure change & $\mathrm{PC}$ & I & I & I & 18 \\
\hline & - Restoration success & RS & / & / & l & 18 \\
\hline & - No prediction & NO & / & / & l & 27 \\
\hline
\end{tabular}




\begin{tabular}{|c|c|c|c|c|c|c|}
\hline Link to ecology & - Link to ecology & LE & 1 & 1 & 1 & 46 \\
\hline \multirow{4}{*}{$\begin{array}{l}\text { Strengths/Gaps of the } \\
\text { method }\end{array}$} & - Easy to apply & EA & / & / & / & 18 \\
\hline & - Variable data series length & DL & / & / & / & 18 \\
\hline & - Gauged / Ungauged stations & $\mathrm{G} / \mathrm{U}$ & / & / & / & 36 \\
\hline & - A priori pressure assessment & $\mathrm{AP}$ & / & / & / & 55 \\
\hline \multicolumn{3}{|l|}{ (b) Recorded features } & \multicolumn{4}{|c|}{$\%$} \\
\hline \multirow[t]{9}{*}{ Channel features } & - Channel pattern & $\mathrm{CP}$ & 55 & 13 & 82 & 1 \\
\hline & - Channel form & $\mathrm{CF}$ & 78 & 27 & 86 & 1 \\
\hline & - Channel dimension & $\mathrm{CD}$ & 84 & 33 & 73 & / \\
\hline & - Flow type & FT & 36 & 7 & 27 & l \\
\hline & - Substrate & SB & 85 & 20 & 82 & l \\
\hline & - Physical parameters & PP & / & 1 & 32 & l \\
\hline & - In-channel vegetation & IV & 62 & 20 & 27 & l \\
\hline & - Woody debris & WD & 62 & 27 & 50 & l \\
\hline & - Artificial features and structures & $\mathrm{AF}$ & 75 & 27 & 77 & / \\
\hline \multirow{11}{*}{$\begin{array}{l}\text { Banks / Riparian zone } \\
\text { features }\end{array}$} & - Bank profile/shape & $\mathrm{BP}$ & 66 & 27 & 82 & I \\
\hline & - Bank material & $\mathrm{BM}$ & 33 & 20 & 36 & / \\
\hline & - Riparian vegetation structure & VS & 71 & 93 & 64 & l \\
\hline & - Riparian vegetation continuity & $\mathrm{VC}$ & 52 & 67 & 32 & l \\
\hline & - Riparian vegetation width & VW & 38 & 53 & 27 & l \\
\hline & - Species composition & SP & / & 73 & 18 & l \\
\hline & - Species coverage/distribution & $\mathrm{SC}$ & / & 80 & / & l \\
\hline & - Vegetation regeneration & VR & / & 60 & / & l \\
\hline & - Riparian soil & RS & / & 20 & / & l \\
\hline & - Artificial features and structures & $\mathrm{AF}$ & 73 & 47 & 77 & l \\
\hline & - Land use & LU & 63 & 53 & 46 & / \\
\hline \multirow[t]{4}{*}{ Floodplain features } & - Fluvial forms & FF & 34 & 13 & 46 & I \\
\hline & - Floodplain dimensions & FS & / & / & 41 & / \\
\hline & - Floodplain features & FD & / & / & 32 & / \\
\hline & - Land use & LU & 67 & 40 & 46 & / \\
\hline \multirow[t]{3}{*}{ Large scale characteristics } & - Large scale pressure & LS & 49 & 13 & 68 & I \\
\hline & - Hydrological regime/Discharge & HR & 70 & 27 & 82 & / \\
\hline & - Valley form & $\mathrm{VF}$ & 49 & 7 & 64 & / \\
\hline \multirow[t]{6}{*}{ Hydrological conditions } & - Flow regime & FR & I & I & 1 & 91 \\
\hline & - Discharge & DI & / & 1 & / & 91 \\
\hline & - Change in depth & $\mathrm{CD}$ & / & / & / & 9 \\
\hline & - Velocity & $\mathrm{VE}$ & / & / & / & 9 \\
\hline & - Shear stress & SS & / & / & / & 0 \\
\hline & - Other & $\mathrm{O}$ & / & / & 1 & 27 \\
\hline \multirow[t]{5}{*}{ Metrics of flow regime } & - Magnitude & MG & / & 1 & 1 & 73 \\
\hline & - Frequency & FR & / & 1 & / & 64 \\
\hline & - Duration & DU & / & / & 1 & 82 \\
\hline & - Timing & TI & / & / & / & 91 \\
\hline & - Rate of change & $\mathrm{RC}$ & / & / & / & 55 \\
\hline
\end{tabular}




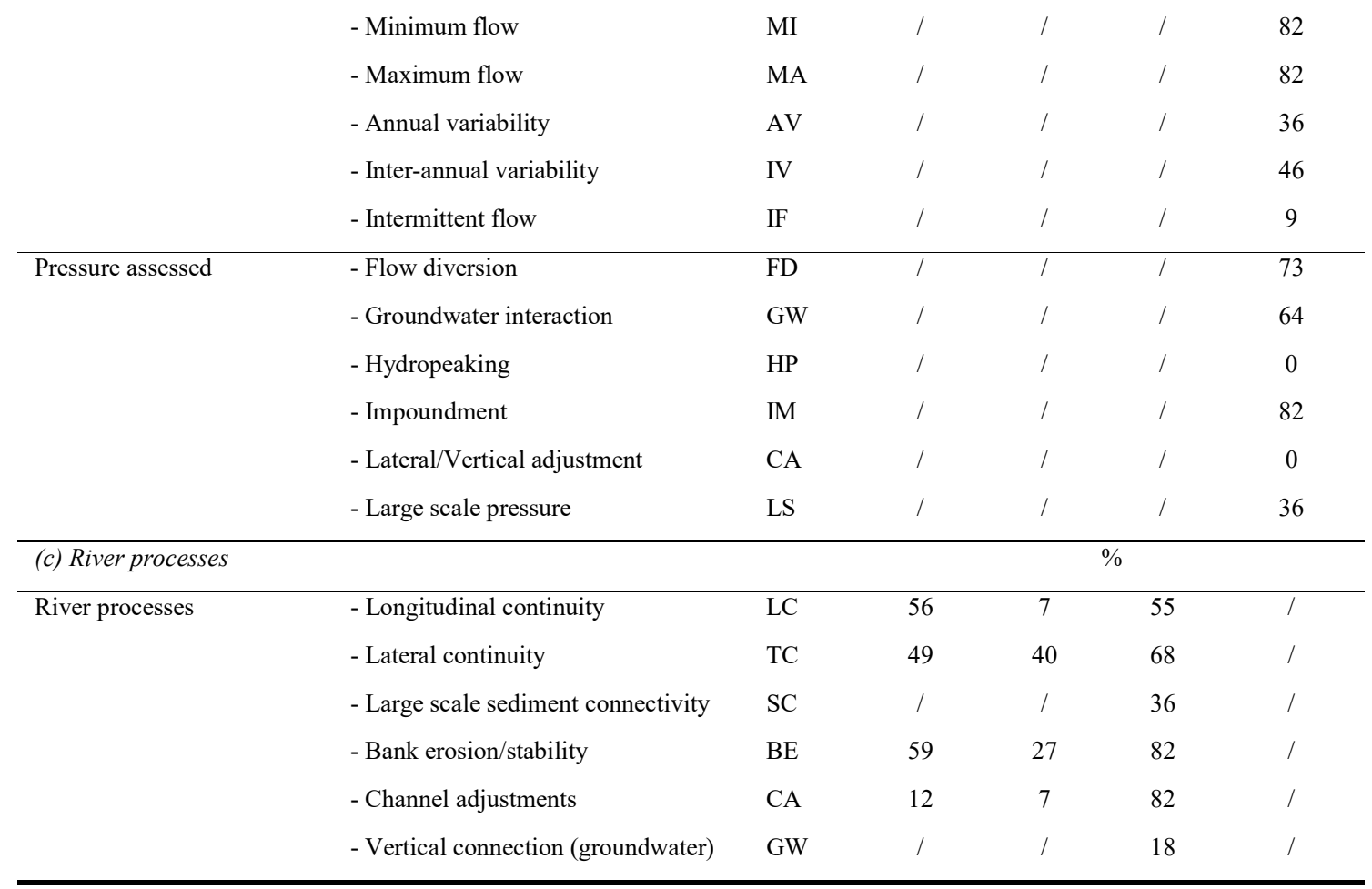


Table 3 Summary of strengths and limitations for each method category

\begin{tabular}{|c|c|c|}
\hline & Strengths & Limitations \\
\hline \multirow[t]{6}{*}{$\mathrm{PH}$} & 1. Framework for habitat inventory & 1. Small and usually fixed spatial scale \\
\hline & 2. Ecological relevance & 2. Detailed, time-consuming data collection \\
\hline & 3. Widely used & $\begin{array}{l}\text { 3. Limited use of geomorphological methods and } \\
\text { remote sensing }\end{array}$ \\
\hline & & 4. Static approach \\
\hline & & $\begin{array}{l}\text { 5. Local assessment of 'natural' state, which } \\
\text { corresponds to feature presence/absence }\end{array}$ \\
\hline & & $\begin{array}{l}\text { 7. Outdated terminology and incomplete coverage of } \\
\text { geomorphic units (and channel patterns) }\end{array}$ \\
\hline \multirow[t]{5}{*}{$\mathrm{RH}$} & \multirow{2}{*}{$\begin{array}{l}\text { 1. Focus on riparian zone and } \\
\text { vegetation }\end{array}$} & 1. Limited consideration of processes \\
\hline & & 2. Poorly developed/used (e.g., mainly in the \\
\hline & \multirow{2}{*}{$\begin{array}{l}\text { 2. Recent development of hymo } \\
\text { integrating approaches (e.g., remote } \\
\text { sensing, reach scale) }\end{array}$} & Mediterranean areas of EU) \\
\hline & & Additional limitations, as for $\mathrm{PH}$ methods \\
\hline & 3. Including strengths of $\mathrm{PH}$ & \\
\hline \multirow[t]{6}{*}{$\mathrm{M}$} & \multirow{2}{*}{$\begin{array}{l}\text { 1. Robust geomorphological-based } \\
\text { approach }\end{array}$} & 1. Physical processes difficult to assess rigorously \\
\hline & & 2. Temporal component difficult to assess \\
\hline & $\begin{array}{l}\text { 2. Use of geomorphologically- } \\
\text { meaningful spatial scale (i.e., reach) }\end{array}$ & 3. Several definitions of reference state \\
\hline & \multirow[t]{3}{*}{ 3. Account for temporal component } & $\begin{array}{l}\text { 4. Assessment of vertical continuity not explicitly } \\
\text { included }\end{array}$ \\
\hline & & 5. Limited consideration of physical habitats \\
\hline & & 6. Lack of linkages with biological components \\
\hline \multirow[t]{4}{*}{ HRA } & \multirow[t]{4}{*}{ 1. Robust approaches (indicators) } & 1. Need for a large dataset and long-time series \\
\hline & & 2. Difficult to define unaltered hydrological regime \\
\hline & & 3. Short time scales not included (e.g., hydropeaking) \\
\hline & & 4. Groundwater alteration not included \\
\hline
\end{tabular}


FIGURES CAPTIONS

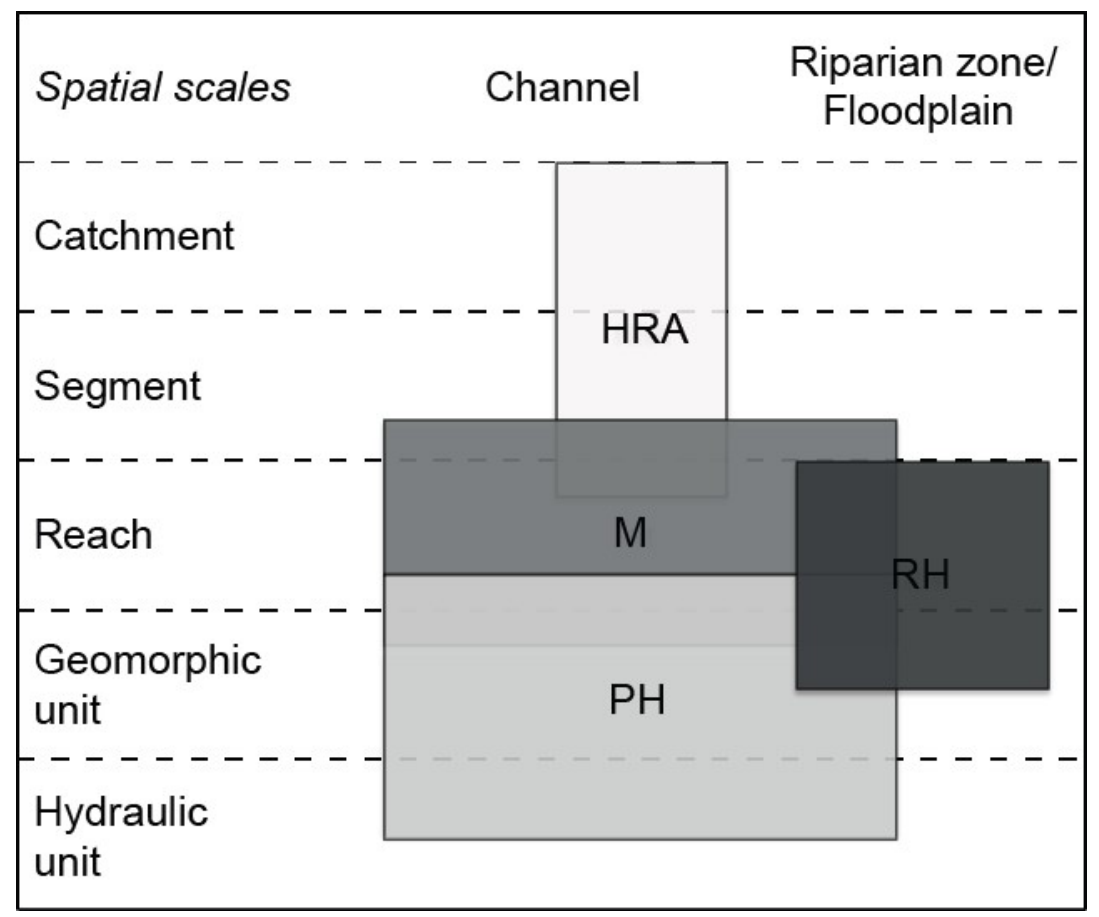

Fig. 1 Spatial context, spatial scales and overlap between assessment method categories. PH: physical habitat assessment; RH: riparian habitat assessment; M: morphological assessment; HRA: hydrological regime alteration assessment

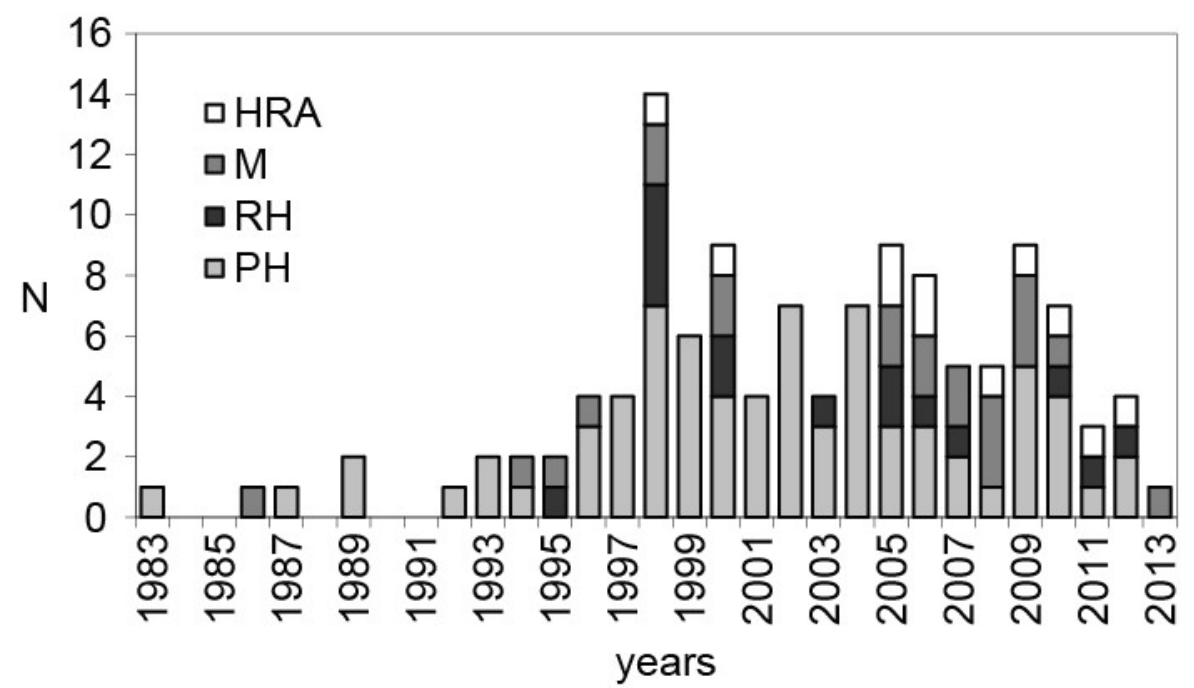

Fig. 2 Chronological appearance of hydromorphological assessment methods grouped into four categories. 


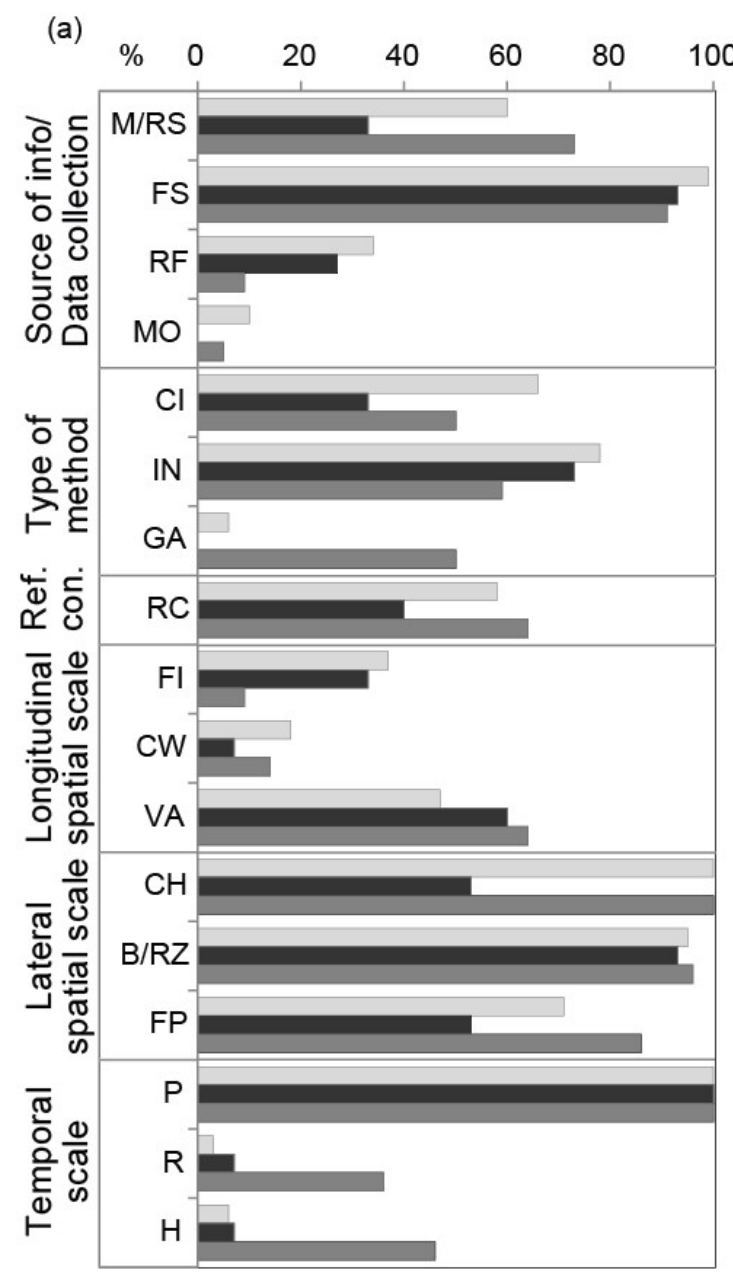

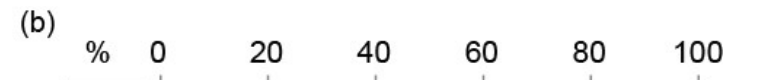

(c)
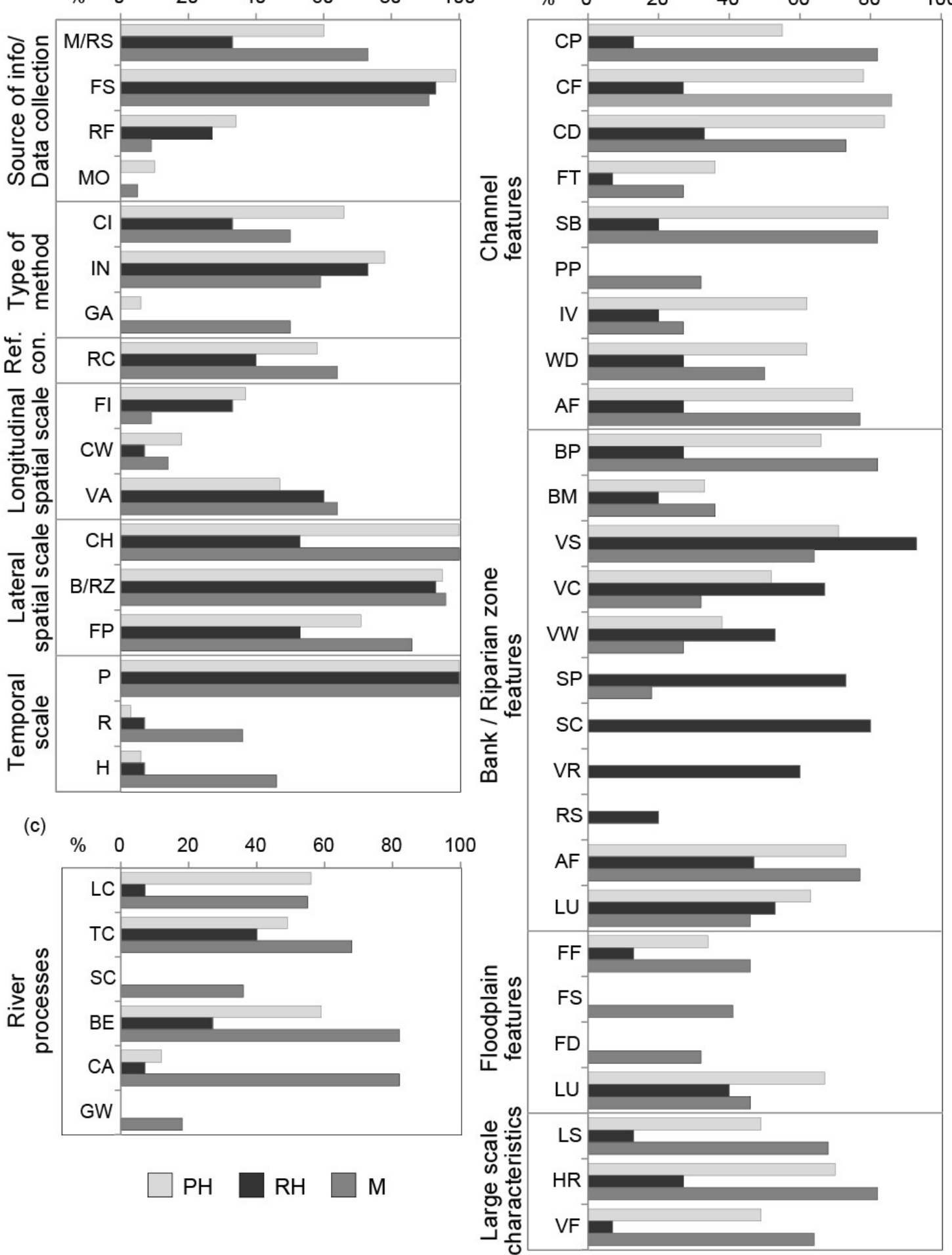

Fig. 3 Analysis of (a) method characteristics; (b) recorded features; (c) processes incorporated in the reviewed physical habitat $(\mathrm{PH})$, riparian habitat $(\mathrm{RH})$, and morphological (M) assessment methods. For abbreviations see Table 2. 


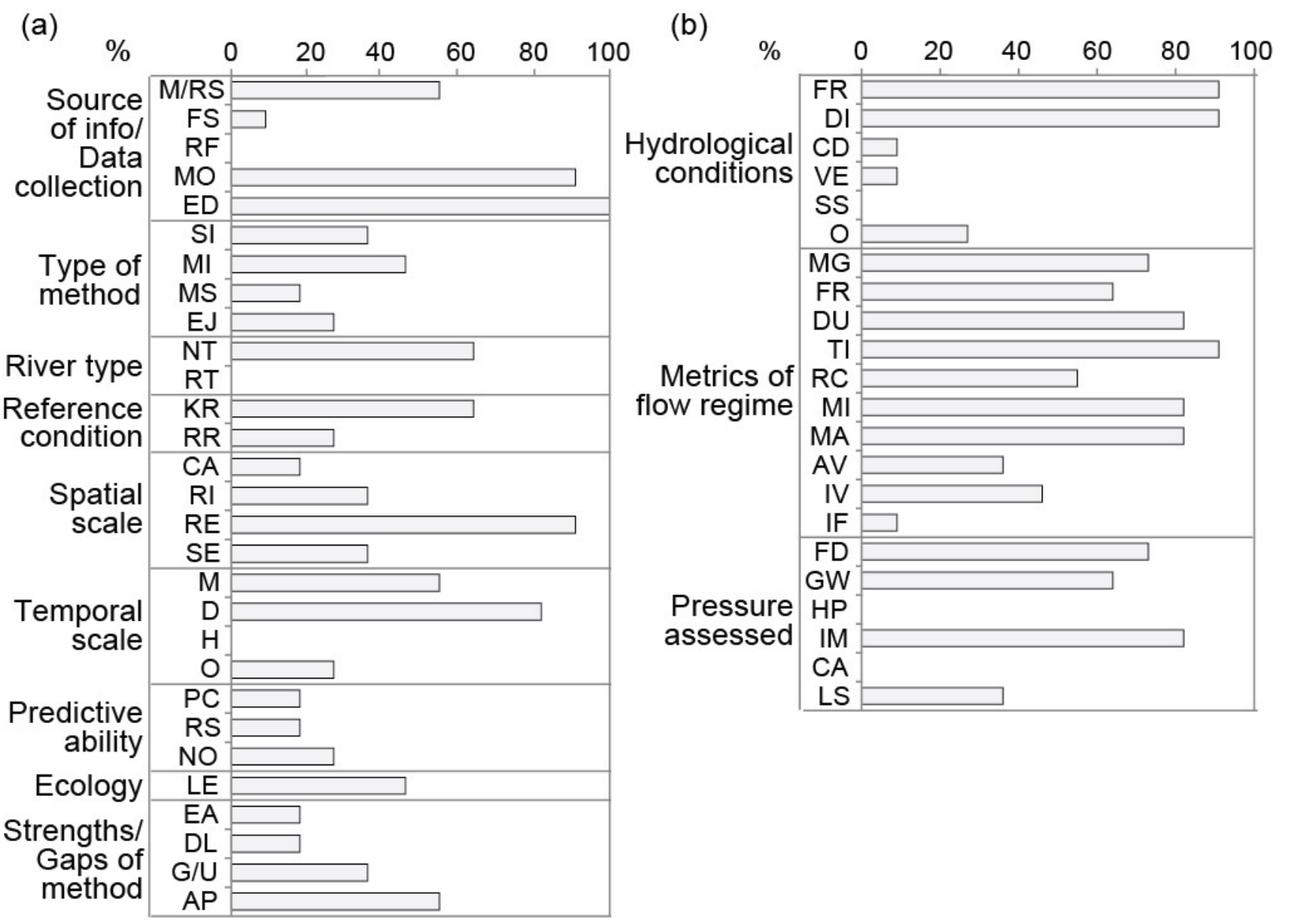

Fig. 4 Analysis of (a) method characteristics; (b) recorded features incorporated in the reviewed methods of assessment of hydrological regime alteration (HRA). For abbreviations see Table 2 .

(a)

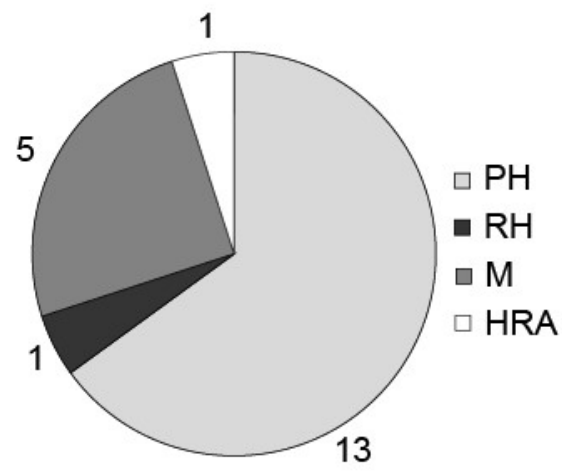

Europe WFD (b)

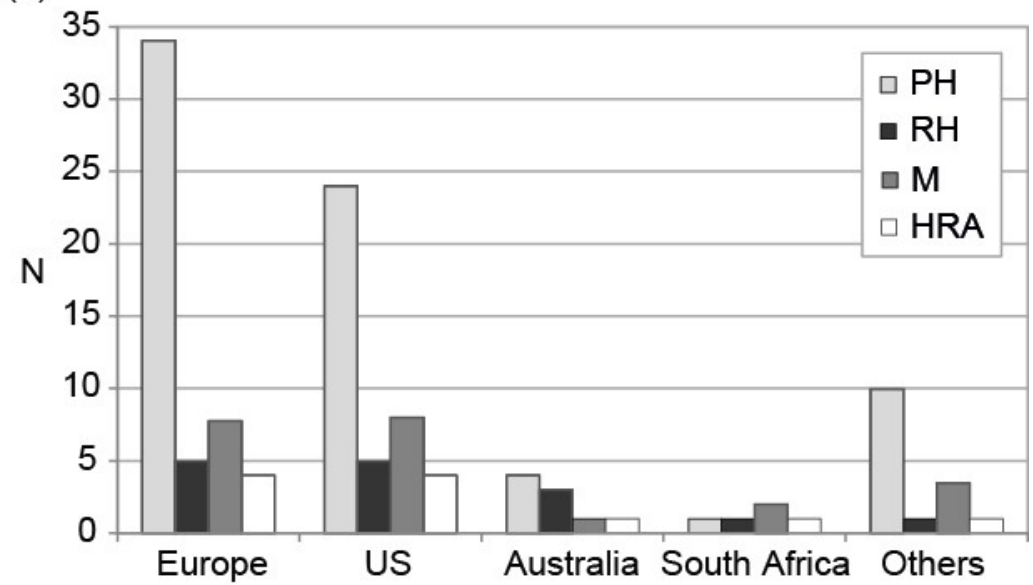

Fig. 5 Number of reviewed methods, sub-divided according to the assessment category, used by: (a) European countries for the implementation of the Water Framework Directive; (b) European (in general, not only for the WFD) and non-EU countries, where "Others" refers to Canada, China, New Zeeland, Switzerland, Ukraine. 